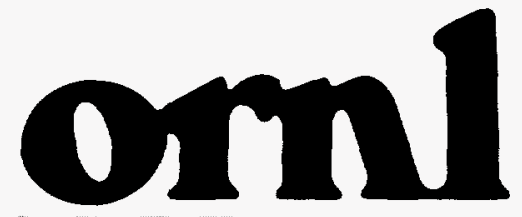

OAK RIDGE

NATIONAL

LABORATORY
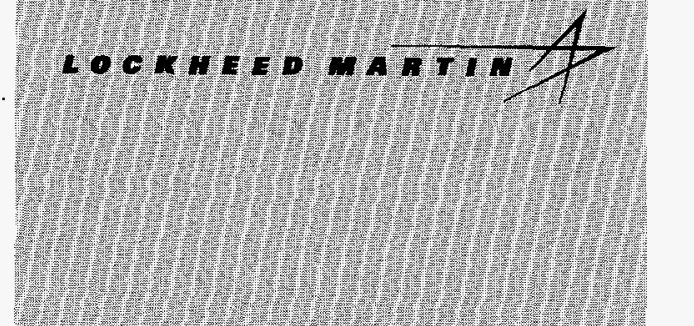

+1) (1):

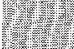

1.

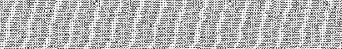$$
\text { 17. }
$$$$
\text { 1) }
$$

RECEIVED

ORNL/TM-13665

\section{Preliminary Assessment of the Nuclide Migration from the Activation Zone Around the Proposed Spallation Neutron Source Facility}

\author{
Leslie R. Dole
}

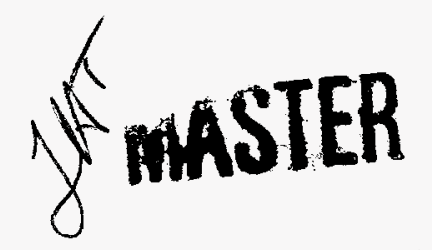

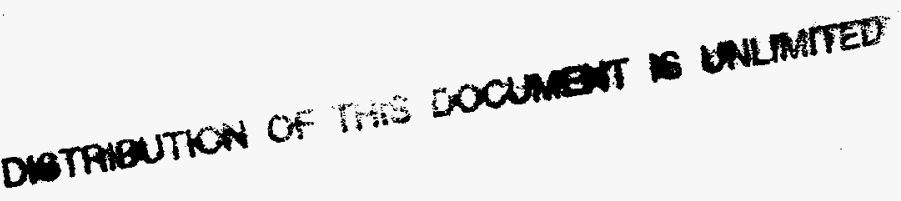


This report has been reproduced directly from the best available copy.

Available to DOE and DOE contractors from the Office of Scientific and Technical Information, P.O. Box 62, Oak Ridge, TN 37831; prices available from (423) 576-8401, FTS 626-8401.

This report was prepared as an account of work sponsored by an agency of the United States Government. Neither the United States Government nol any agency thereof, nor any of their employees, makes any warranty, express or implied, or assumes any legal liability or responsibility for the accuracy, completeness, or usefulness of any information, apparatus, product, or process disclosed, or represents that its use would not infringe privately owned rights. Reference herein to any specific commercial product, process, or service by trade name, trademark, manufacturer, or otherwise, does not necessarily constitute or imply its endorsement, recommendation, or favoring by the United States Government or any agency thereof. The views and opinions of authors expressed herein do not necessarily state or reflect those of the United States Government or any agency thereof. 


\section{DISCLAIMER}

Portions of this document may be illegible in electronic image products. Images are produced from the best available original document. 
Chemical Technology Division

\title{
PRELIMINARY ASSESSMENT OF THE NUCLIDE MIGRATION FROM THE ACTIVATION ZONE AROUND THE PROPOSED SPALLATION NEUTRON SOURCE FACILITY
}

Leslie R. Dole

Date Published: September 1998

\author{
Prepared by \\ OAK RIDGE NATIONAL LABORATORY \\ Oak Ridge, Tennessee 37831-6285 \\ managed by \\ LOCKHEED MARTIN ENERGY RESEARCH CORP. \\ for the \\ U.S. DEPARTMENT OF ENERGY \\ under contract DE-AC05-96OR22464
}





\section{CONTENTS}

Page

LIST OF FIGURES $\ldots \ldots \ldots \ldots \ldots \ldots \ldots \ldots \ldots \ldots \ldots \ldots \ldots \ldots \ldots \ldots$

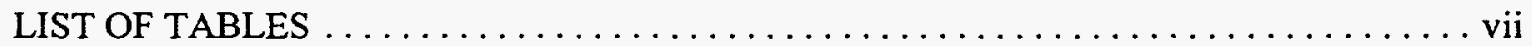

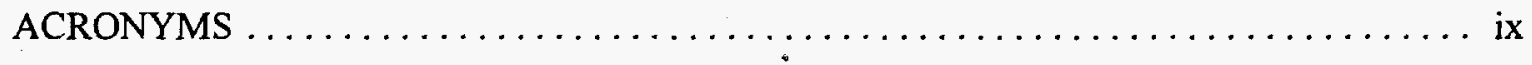

1. EXECUTIVE SUMMARY $\ldots \ldots \ldots \ldots \ldots \ldots \ldots \ldots \ldots \ldots \ldots \ldots \ldots \ldots \ldots \ldots \ldots \ldots$

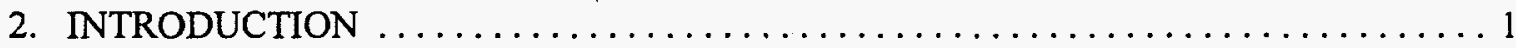

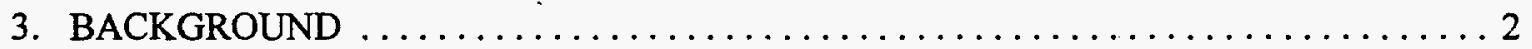

4. ESTIMATES AND ASSUMPTIONS OF ACTIVATION PRODUCTS FOR THE PROPOSED LINAC ACCELERATOR TUNNEL SHIELD BERM $\ldots \ldots \ldots \ldots \ldots \ldots 3$

5. POTENTIAL TRANSPORT MECHANISMS AND SIMPLIFYING ASSUMPTIONS $\ldots 6$ 5.1 ASSUMPTIONS OF TOTAL CONTAMINANT AVAILABILITY

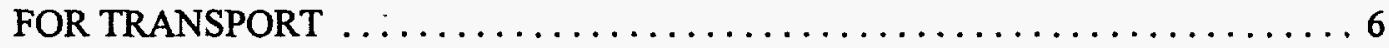

5.2 NO ADVECTIVE FLOW THROUGH THE SHIELD BERM $\ldots \ldots \ldots \ldots \ldots \ldots .7$

5.3 DIFFUSION FROM SHIELD BERM WITH NO RETARDATION

INTO THE SURROUNDING SOIL $\ldots \ldots \ldots \ldots \ldots \ldots \ldots \ldots \ldots \ldots \ldots$

5.3.1 Estimating the Retardation Factors and the Diffusion Coefficients . . . . . . 10

5.3.2 Diffusion-Controlled Contaminant Releases from the Shield Berm . . . . . . 12

5.3.2.1 Semiinfinite-Medium Diffusion Model . . . . . . . . . . . . . . . 13

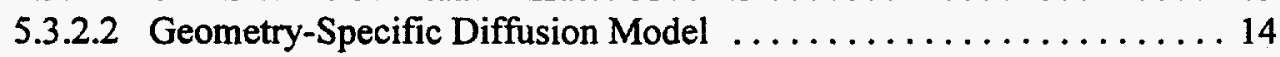

5.4 SNS HYDROLOGICAL SETTING AND ASSUMPTIONS $\ldots \ldots \ldots \ldots \ldots \ldots \ldots$

5.5 DECAY OF ISOTOPES DURING DIFFUSION AND TRANSPORT $\ldots \ldots \ldots \ldots 17$

5.6 SUMMARY OF ASSUMPTIONS AND THEIR EFFECTS ON THE ANALYSES .. 18

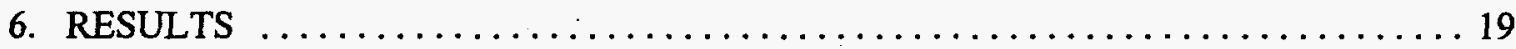

7. RECOMMENDED DESIGN MODIFICATIONS AND

SUGGESTED LABORATORY MEASUREMENTS $\ldots \ldots \ldots \ldots \ldots \ldots \ldots \ldots \ldots \ldots \ldots$

7.1 RECOMMENDED ȘHIELD-BERM MODIFICATIONS $\ldots \ldots \ldots \ldots \ldots \ldots \ldots 21$

7.1.1 Crushed Limestone Capillary Break To Isolate Berm from Local Hydrology . . 21

7.1.2 Calcium Hydroxide Berm Additive for ${ }^{14} \mathrm{C}$ Retention . . . . . . . . . . 22

7.1.3 Berm Additive for ${ }^{22} \mathrm{Na}$ and ${ }^{54} \mathrm{Mn}$ Retention (Amorphous Silica) . ........ 24

7.1.4 Concentric Combination of Coarse Limestone and Compacted Clays . . . . . . . . 24

7.1.4.1 Case Studies of Concentric Combinations of Limestone

and Compacted Clays . . . . . . . . . . . . . . . . . . . 28

7.1.4.2 Estimates of Activation Products Formed in the Concentric Shield . . 29

7.1.4.3 Estimates of the Concentrations of Activation Products

in the Concentric Shield . . . . . . . . . . . . . . . . . . 31

7.1.4.4 Retention of Activation Products in the Inner Limestone . . . . . . . 32

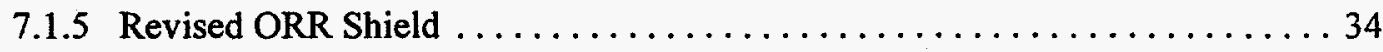




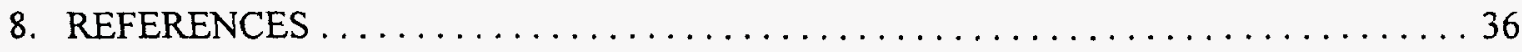

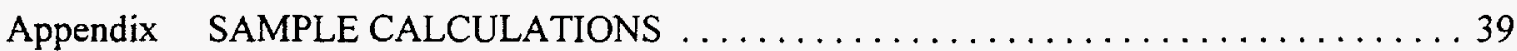




\section{LIST OF FIGURES}

Figure

Page

1 This illustrates the model used to calculate the activation products within the first $4 \mathrm{~m}$ beyond the outer SNS tunnel wall, where $99.9 \%$ of all curies of activation products are formed $\ldots \ldots \ldots \ldots \ldots \ldots \ldots$

2 If groundwater will flow around, rather than through, the shield-berm matrix, releases will be diffusion controlled

3 Hydrologic cross section of the proposed SNS site used in the calculation of potential contaminant concentrations at the boundary of a $10-\mathrm{m}$ zone of influence

4 Details of the proposed concentric-barriers concept for the shield berm

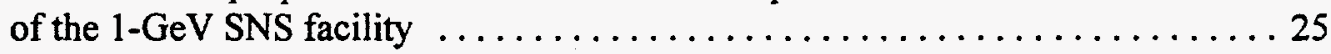

5 Diffusion rates slow, and the slopes of the plots decrease

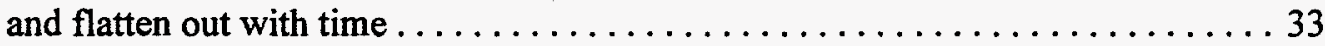

6 Combined effects of diffusion and radioactive decay of the activation products from limestone riprap $\ldots \ldots \ldots \ldots \ldots \ldots \ldots \ldots \ldots$ 


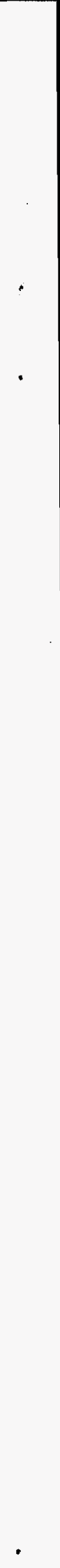




\section{LIST OF TABLES}

Table

1 Properties of the principal long-lived isotopes of concern in the

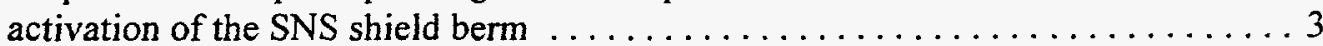

2 Conservative estimates of the curies of long-lived nuclides formed after 30 years of Linac operations at $1 \mathrm{MW}$ in the last $20 \mathrm{~m}$ of highest beam energy with protons at $1 \mathrm{GeV}$ extrapolated over the entire $958-\mathrm{m}$ length of the SNS beam-tunnel system $(47.9$ times $) \ldots \ldots \ldots \ldots \ldots \ldots \ldots$

3 Calculated effective diffusion coefficients $\left(D_{e}\right)$ using Oak Ridge soils for the compacted shield berm and retardation coefficients $(R)$ for the surrounding native, uncompacted soils $\ldots \ldots \ldots \ldots \ldots \ldots \ldots \ldots \ldots \ldots \ldots$

4 Estimated uniform distribution of isotopes in the SNS shield berm over its length and diameter at the end of 30 years of operations and no retardation in the surrounding soil of the isotopes' migration to a distance of $10 \mathrm{~m}$ in the first 10 years after closure $\ldots \ldots \ldots \ldots \ldots \ldots 20$

5 SNS nuclide concentrations (in microcuries per gram) compared with

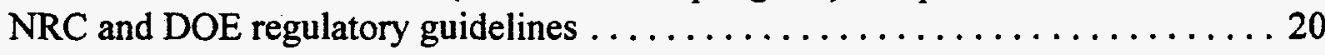

6 Summary of two concentric shielding configuration case studies $\ldots \ldots \ldots \ldots 28$

7 Case 1: Conservative estimates of the concentrations (in curies) of long-lived nuclides for case 1 formed after 30 years of Linac operation in the last $20 \mathrm{~m}$ of the highest beam energy with $1 \mathrm{MW}$ of protons at $1 \mathrm{GeV}$ extrapolated over the entire 958-m length of the SNS beam tunnel system (47.9 times)

8 Case 2: Conservative estimates of the concentrations (in curies) of long-lived nuclides for case 2 formed after 30 years of Linac operation in the last $20 \mathrm{~m}$ of the highest beam energy with $1 \mathrm{MW}$ of protons at $1 \mathrm{GeV}$ extrapolated over the entire $958-\mathrm{m}$ length of the SNS beam tunnel

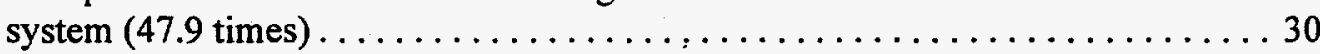

9 Conservative estimates of the concentrations (in microcuries per cubic centimeter) of long-lived nuclides for case 1 formed after 30 years of Linac operation in the last $20 \mathrm{~m}$ of the highest beam energy with $1 \mathrm{MW}$ of protons at $1 \mathrm{GeV}$

10 Conservative estimates of the concentrations (in microcuries per cubic centimeter) of long-lived nuclides for Case 2 formed after 30 years of Linac operation in the last $20 \mathrm{~m}$ of the highest beam energy with $1 \mathrm{MW}$ of protons at $1 \mathrm{GeV}$

11 Diffusion-controlled fractional release from 3- and 6-in. riprap limestone with a $D_{e}$ of $8 \times 10^{-20} \mathrm{~cm}^{2} / \mathrm{s}$ 

ASTM American Society for Testing and Materials

CFR Code of Federal Regulations

DOE U.S. Department of Energy

DWL Drinking water limit

NRC U.S. Nuclear Regulatory Commission

ORNL Oak Ridge National Laboratory

ORR Oak Ridge Reservation

SLB Shallow land burial

SLD Shallow land disposal

SNS Spallation Neutron Source

SSC Superconducting Super Collider 


\section{EXECUTIVE SUMMARY}

The purpose of this study is to investigate the potential impacts of migrating radionuclides from the activation zone around the proposed Spallation Neutron Source (SNS). Using conservatively high estimates of the potential inventory of radioactive activation products that could form in the proposed compacted-soil shield berm around an SNS facility on the Oak Ridge Reservation (ORR), a conservative, simplified transport model was used to estimate the potential worst-case concentrations of the 12 long-lived isotopes in the groundwater under a site with the hydrologic characteristics of the ORR.

Of the 12 , only 3 isotopes showed any potential to exceed the U.S. Nuclear Regulatory Commission (NRC) 10 Code of Federal Regulations (CFR) Part 20 Drinking Water Limits (DWLs). These isotopes were ${ }^{14} \mathrm{C},{ }^{22} \mathrm{Na}$, and ${ }^{54} \mathrm{Mn}$. The latter two activation products have very short half-lives of 2.6 years and 0.854 year, respectively. Therefore, these will decay before reaching an off-site receptor, and they cannot pose off-site hazards. However, for this extremely conservative model, which overestimates the mobility of the contaminant, ${ }^{14} \mathrm{C}$, which has a 5,730-year half-life, was shown to represent a potential concern in the context of this study's conservative assumptions. This study examines alternative modifications to the SNS shield berm and makes recommendations.

\section{INTRODUCTION}

This work reports a preliminary assessment of the potential for radioactive activation products to migrate from within the soil shield berm, which is to be around the beam tunnels ${ }^{1}$ of the proposed SNS. Using conservative models of the near-field $(\leq 10-\mathrm{m})$ transport mechanisms within and adjacent to the shielding berm, this study estimates the potential rates and quantities of radionuclides that could be released following 30 years of continuous accelerator operations and during the initial postclosure period of a "mothball and abandon-in-place" decommissioning scenario.

This study recommends modifications to the current compacted-soil shield-berm design to mitigate the potential migration of the activation products. This work also suggests laboratory analyses to verify the conservatism of this study and to measure key transport parameters on the site-specific native soils and proposed shield-berm components. 


\section{BACKGROUND}

Accelerators produce particles that diffuse outward from the core of the beam into its halo. These high-energy particles strike beam-line components. ${ }^{2}$ As these high-energy particles $(\mathrm{GeV})^{*}$ interact with matter, such as occurs in the beam magnets and other parts of the SNS structure, they initiate a series of nuclear interactions. These interaction are called "stars." These stars produce secondary particles which also interact with their surrounding matter, producing more stars in a cascade until the particle energies of the stars fall below the thresholds for further nuclear reactions-the megaelectron volt $(\mathrm{MeV})$ level.

Some of these secondary particles escape the beam-line components, causing star cascades in the accelerator tunnel structures and surrounding soil, and activate the adjacent soils used for shielding. The quantity of activation products in the adjacent berm is proportional to the number of stars produced in the shield's soil minerals and pore water. Analyses show that $99.9 \%$ of the curies are contained within the first $4 \mathrm{~m}$ perpendicular to the beam tunne $\mathrm{P}^{3}$ and beyond the outer surface of the tunnel's concrete structure. A general approximation is that the star density decreases by a factor of $10\left(10^{-1}\right)$ for each meter of soil shielding.

Table 1 lists the principal isotopes with longer half-lives ( $>1$ year) that are estimated to build up in the shield-berm activation zone, assuming 30 years of continuous operations at $1 \mathrm{MW}$. This is a very conservative, high estimate because the beam does not operate continuously over its 40 years of projected facility life. Therefore, the estimates of nuclide quantities in Table 2 are much higher than those actually expected. Also, one of the goals of this new facility's design is to significantly reduce beam leakage, which, in turn, should significantly reduce the actual concentrations of these activation products.

This study also assumes that these activation products remain in the matrix of the berm and do not begin moving until the end of the facility's operations. This assumption ensures that this study is based on the maximum credible or "incredible" starting concentrations of activation products. Also, this study assumes that the inventory of activation products within the tunnel's concrete structure does not contribute significantly to the inventory of mobile nuclides.

\footnotetext{
${ }^{*} 1 \mathrm{GeV}=1$ gigaelectron volt $=1.60219 \times 10^{-10} \mathrm{joule}$, where 1 joule $=1$ newton $\times 1 \mathrm{~m}$.
} 


\begin{tabular}{|l|c|c|c|c|c|c|}
\hline \multicolumn{7}{|c|}{ Table 1. Properties of the principal long-lived isotopes of concern } \\
in the activation of the SNS shield berm
\end{tabular}

${ }^{a}$ E.C. $=$ orbital electron capture.

If the shield-berm soils are hydraulically connected to the local groundwater recharge and transport system, there is a potential for these radioactive activation products to migrate into the area's groundwater supply. This potential for migration is the basis of this study.

\section{ESTIMATES AND ASSUMPTIONS OF ACTIVATION PRODUCTS FOR THE PROPOSED LINAC ACCELERATOR TUNNEL SHIELD BERM}

The 493-m-long Linac beam, storage ring, and beam transition apparatus are to be contained within 18-ft-square (outside dimension), reinforced concrete tunnels with a total length of $958 \mathrm{~m}$. These tunnels are to be surrounded with a compacted mixture of local soil, clay, and sand (Fig. 1). This compacted shield berm is to be at least $4 \mathrm{~m}$ thick and will be the primary shielding for the activated beam components and the concrete tunnel structure. The soil mixture will be compacted to a Darcy permeability of less than $1 \times 10^{-7} \mathrm{~cm} / \mathrm{s}$ and will also be a hydrologic barrier to advective"* water and contaminant transport. The berm is then a barrier to groundwater transport of the activation products distributed throughout its matrix.

\footnotetext{
* A standard unit of permeability equivalent to the passage of $1 \mathrm{~cm}^{3} / \mathrm{s}$ of water at 1 centipoise through a porous media having a cross-sectional area of $1 \mathrm{~cm}^{2}$ and a depth of $1 \mathrm{~cm}$.

** A contiguous fluid moved by a pressure gradient.
} 


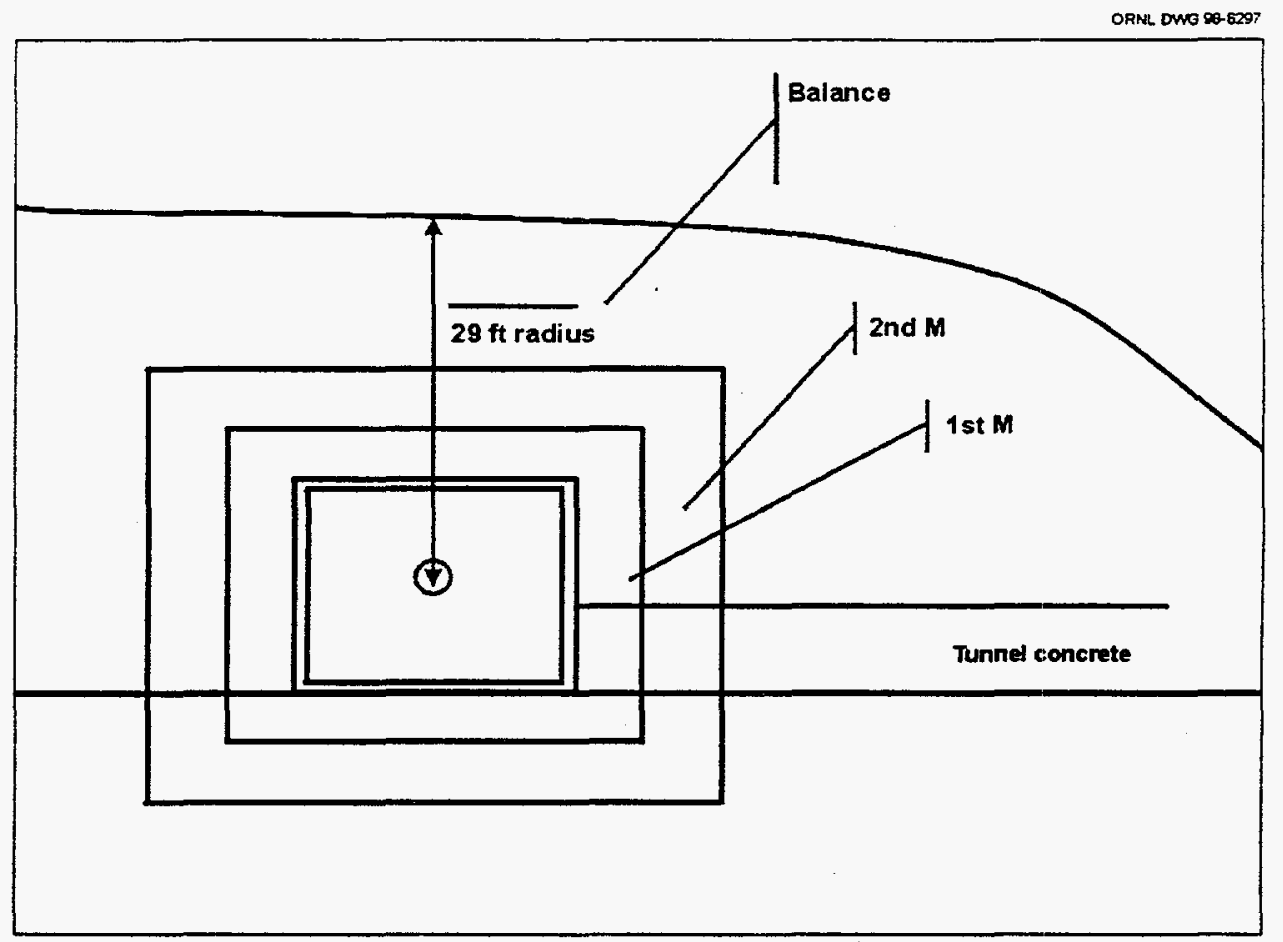

Fig. 1. This illustrates the model used to calculate the activation products within the first $4 \mathrm{~m}$ beyond the outer SNS tunnel wall, where $99.99 \%$ of all curies of activation products are formed.

The current conservative estimates of the activation products formed in the proposed soil berm of the Linac were performed by Jeff Johnson of the Oak Ridge National Laboratory (ORNL) (Jeff Johnson, ORNL, personal communication to Les Dole, Chemical Technology Division, ORNL) and are based on calculations using the worst-case beam leakage at the highenergy end of this Linac beam, which has protons at $1 \mathrm{GeV}$ with a beam power of $1 \mathrm{MW}$. His calculations used a reference soil as the model for predicting the activation products and their quantities.

The reference soil used to estimate these nuclide quantities was an Aberdeen marinedeposited soil and is expected to differ from the Copper Ridge dolomite residuum on the ORR. However, the resulting activation products are determined by the elemental composition of a soil. While the soil matrix varies greatly between the four alternative sites for SNS, the major constituents of silicon, oxygen, and aluminum are common to all soils. Therefore, the suite of activation products at ORNL, Los Alamos National Laboratory, Argonne National Laboratory, and Brookhaven National Laboratory will not be identical to that at Aberdeen but will be close 
enough for the intended purpose, which is to investigate the potential impacts of migrating radionuclides from the activation zone around the proposed SNS.

The activation rates are based on projected particle leakage from the highest-energy section of the beam at $1 \mathrm{GeV}$ and are characteristic of the last $20 \mathrm{~m}$ of the $493-\mathrm{m}$-long Linac accelerator, the beam storage ring, and the beam transfer tunnels.

This study conservatively assumed that these highest concentrations of activation products in curies (Ci) ${ }^{*}$ were distributed over the entire length of the beam tunnel with both axial and linear homogeneity. For the nuclides with half-lives $\geq 1$ year, the calculated results for the last $20 \mathrm{~m}$ are summarized in Table 2. Since the total SNS beam-tunnel system is $958 \mathrm{~m}$ long, multiplying the 20 -m quantities in the next-to-last column of Table 2 by 47.9 extrapolates these worst-case quantities over the entire length of the accelerator facility (Table 2, last column).

\begin{tabular}{|c|c|c|c|c|c|c|c|}
\hline \multirow[b]{2}{*}{ Isotope } & \multirow[b]{2}{*}{$\begin{array}{c}\text { Half-life } \\
\text { (year) }\end{array}$} & \multirow[b]{2}{*}{$\begin{array}{l}\text { Concrete } \\
\text { tunnel } \\
\text { (Ci) }\end{array}$} & \multicolumn{5}{|c|}{ Total } \\
\hline & & & $1 \mathrm{st} \mathrm{m}$ & $2 d m$ & $\begin{array}{l}\text { 3rd and } \\
\text { 4th } m\end{array}$ & $\begin{array}{l}\text { Within lst } \\
\text { through } \\
\text { 4th } \mathrm{m} \text { of } \\
\text { berm shield } \\
\text { over } 20 \mathrm{~m}\end{array}$ & $\begin{array}{l}\text { Within 1st } \\
\text { through } \\
\text { 4th } \mathrm{m} \text { of } \\
\text { berm shield } \\
\text { over } 958 \mathrm{~m}\end{array}$ \\
\hline $\begin{array}{l}{ }^{3} \mathrm{H} \\
{ }^{10} \mathrm{Be} \\
{ }^{14} \mathrm{C} \\
22 \mathrm{Na} \\
{ }^{26} \mathrm{Al} \\
{ }^{36} \mathrm{Cl} \\
{ }^{30} \mathrm{Ar} \\
{ }^{40} \mathrm{~K} \\
{ }^{41} \mathrm{Ca} \\
{ }^{53} \mathrm{Mn} \\
{ }^{54} \mathrm{Mn} \\
{ }^{53} \mathrm{Fe}\end{array}$ & $\begin{array}{l}1.23 \mathrm{E}+01 \\
1.50 \mathrm{E}+06 \\
5.73 \mathrm{E}+03 \\
2.60 \mathrm{E}+00 \\
7.15 \mathrm{E}+05 \\
3.01 \mathrm{E}+05 \\
2.69 \mathrm{E}+02 \\
1.27 \mathrm{E}+09 \\
1.03 \mathrm{E}+05 \\
3.70 \mathrm{E}+06 \\
8.50 \mathrm{E}-01 \\
2.73 \mathrm{E}+00\end{array}$ & $\begin{array}{l}5.44 \mathrm{E}-07 \\
2.09 \mathrm{E}-01 \\
1.07 \mathrm{E}+02 \\
2.22 \mathrm{E}-03 \\
2.55 \mathrm{E}+04 \\
4.82 \mathrm{E}+03 \\
2.69 \mathrm{E}+01 \\
1.50 \mathrm{E}+10 \\
9.83 \mathrm{E}+05 \\
3.00 \mathrm{E}+03 \\
1.10 \mathrm{E}-04 \\
1.23 \mathrm{E}-01\end{array}$ & $\begin{array}{l}4.045 E-04 \\
3.508 E-06 \\
2.744 E+00 \\
5.828 E+00 \\
3.909 E-03 \\
1.526 E-03 \\
6.738 E+00 \\
4.765 E-05 \\
1.500 E-02 \\
2.910 E-05 \\
5.079 E+03 \\
3.910 E+02\end{array}$ & $\begin{array}{l}5.711 \mathrm{E}-05 \\
4.952 \mathrm{E}-07 \\
3.874 \mathrm{E}-01 \\
8.228 \mathrm{E}-01 \\
5.518 \mathrm{E}-04 \\
2.154 \mathrm{E}-04 \\
9.513 \mathrm{E}-01 \\
6.728 \mathrm{E}-06 \\
2.118 \mathrm{E}-03 \\
4.108 \mathrm{E}-06 \\
7.171 \mathrm{E}+02 \\
5.520 \mathrm{E}+01\end{array}$ & $\begin{array}{l}1.404 \mathrm{E}-05 \\
1.217 \mathrm{E}-07 \\
9.523 \mathrm{E}-02 \\
2.023 \mathrm{E}-01 \\
1.357 \mathrm{E}-04 \\
5.295 \mathrm{E}-05 \\
2.339 \mathrm{E}-01 \\
1.654 \mathrm{E}-06 \\
5.206 \mathrm{E}-04 \\
1.010 \mathrm{E}-06 \\
1.763 \mathrm{E}+02 \\
1.357 \mathrm{E}+01\end{array}$ & $\begin{array}{l}4.757 \mathrm{E}-04 \\
4.124 \mathrm{E}-06 \\
3.227 \mathrm{E}+00 \\
6.853 \mathrm{E}+00 \\
4.596 \mathrm{E}-03 \\
1.794 \mathrm{E}-03 \\
7.923 \mathrm{E}+00 \\
5.604 \mathrm{E}-05 \\
1.764 \mathrm{E}-02 \\
3.421 \mathrm{E}-05 \\
5.973 \mathrm{E}+03 \\
4.598 \mathrm{E}+02\end{array}$ & $\begin{array}{l}2.278 E-02 \\
1.976 E-04 \\
1.546 E+02 \\
3.283 E+02 \\
2.202 E-01 \\
8.593 E-02 \\
3.795 E+02 \\
2.684 E-03 \\
8.448 E-01 \\
1.639 E-03 \\
2.861 E+05 \\
2.202 E+04\end{array}$ \\
\hline \multicolumn{2}{|c|}{$20-m$ concrete total } & $1.50 \mathrm{E}+10$ & & & Total & $6.451 \mathrm{E}+03$ & $3.090 \mathrm{E}+05$ \\
\hline
\end{tabular}

The conservative assumption is that the activation in the last $20 \mathrm{~m}$ of the Linac berm represents the entire length of the facility's berm tunnels. This results in a conservative estimate that there would be a potential $3.09 \times 10^{5} \mathrm{Ci}$ of radionuclides that has accumulated in the first

\footnotetext{
*A unit of radioactivity, equal to the amount of a radioactive isotope that decays at the rate of $3.7 \times 10^{10}$ disintegrations per second (becquerel).
} 
$4 \mathrm{~m}$ of the soil shield berm after 30 years of continuous SNS operations. This is a conservatively high estimate of potential risks from neutron activations.

In the example of the SNS concrete tunnel structures, the coarse aggregate and the cement's high silica content, low permeability, and high alkalinity tenaciously sequester the activation products. Consequently, the activation products in the tunnel's load-bearing structures are not available for transport. Therefore, there is a negligible contribution to the potential environmental risks from nuclides in the SNS concrete tunnel.

\section{POTENTIAL TRANSPORT MECHANISMS AND SIMPLIFYING ASSUMPTIONS}

Two conditions make these analyses different from the usual contaminant-transport analyses, which usually involve a spill of external contamination that is carried through porous soils by a flow of percolating groundwater. First, the activation products start from inside the soils' minerals. Also, in the proposed soils at the Oak Ridge site, advective saturated groundwater flow is not the principal mechanism by which water moves through pores of the soils.

\subsection{ASSUMPTIONS OF TOTAL CONTAMINANT AVAILABILITY FOR TRANSPORT}

Because the radionuclides are produced through activation by high-energy particles scattered from the beam line, contaminants are produced within crystalline structures of the soil's minerals. These minerals form the finely divided primary soil phases. This phenomenon is the opposite of the classic spill scenario during which the contaminants are carried by percolating water into clean soils and their migration potentials are controlled predominantly by the interactions with the surfaces of the soil minerals. In the SNS activation case, most contaminants start out trapped inside the minerals and must first diffuse through the crystalline solids to their surfaces before groundwater-transport phenomena can begin. Therefore, transport, as in the case of the proposed SNS shield berm into the vadose zone, would be controlled more by the rates of solid-state diffusion of the contaminants out of the soil phases than by the relative partitioning between mineral surfaces and moving groundwater.

However, there are few data that measure the behavior of these contaminants and their releases from the soil phases of interest at the proposed SNS sites. While there has been some work on soils and rocks from the proposed Superconducting Super Collider (SSC), ${ }^{4}$ experimental results show a high rate of releases from the local Ellis County, Texas, materials. 
These leaching experiments were very short term (hours and days), and these tests did not address diffusion-controlled release rates. The tests involved soluble mineral phases, such as calcium carbonate and dolomite $\left[\mathrm{CaMg}\left(\mathrm{CO}_{3}\right)_{2}\right]$, that were exposed to distilled water.

Also, these experiments did not use representative regional groundwaters, which are at equilibrium with the local host soils through which they must move. Then, real groundwaters would arrive already saturated with the local minerals' constituents, such as silica $\left(\mathrm{SiO}_{2}\right)$, alumina $\left(\mathrm{Al}_{2} \mathrm{O}_{3}\right)$, dolomite $\left[\mathrm{CaMg}\left(\mathrm{CO}_{3}\right)_{2}\right]$, and iron oxide $\left(\mathrm{Fe}_{2} \mathrm{O}_{3}\right)$. These native saturated groundwaters will characteristically have $350 \mathrm{ppm}$ or more of total dissolved solids, an amount which would substantially reduce the potential for solubilization of the berm soils' minerals as a potential release mechanism.

Based on these SSC data, this study conservatively assumes that over the projected SNS facility life of 40 years and with the fine texture of the currently proposed shield-berm soils, all of the activation products are immediately available for diffusion and subsequent hydraulic transport to the groundwater.

\subsection{NO ADVECTIVE FLOW THROUGH THE SHIELD BERM}

The proposed SNS locations in Oak Ridge are in unsaturated surface soils located above the groundwater table. In the upper unsaturated soil, which is referred to as the vadose zone, the pores are not completely filled with water. The soil particles may be covered with a more-or-less contiguous film of water, but there is also air in the rest of the pore spaces. Therefore, the water in the vadose-area capillaries is not pushed through the soil by a hydraulic pressure gradient; rather, it is drawn through the soil by capillary "wicking." Since the capillary forces are greater in the smaller pores, the ground's moisture is drawn preferentially to the finer-grained soils.

Nevertheless, this study assumes that there can somehow be continuous saturated flow around the outer surface of the shield berm to carry the contaminants to the water table below. Infrequently, there are seasonal episodes in which the vadose zone at West Chestnut Ridge has become saturated, as have bands of saturation migrating from the surface to the water table. This study assumes the unlikely case that saturated flow is constant. Even in this very extreme case, the difference in permeability between the berm and the surrounding native soils prevents significant advection through the berm's matrix.

Since the Darcy permeability of the compacted shield berm is estimated be less than $1 \times 10^{-7} \mathrm{~cm} / \mathrm{s}$ and the surrounding native soils have permeabilities around $1 \times 10^{-5} \mathrm{~cm} / \mathrm{s}$, the berm 
is 100 times less permeable than the surrounding soils. Therefore, saturated water transport must go around the berm rather than through it. ${ }^{5}$ Figure 2 summarizes this effect.

Hence, even if the surrounding soils could become saturated, no significant advective transport through the berm matrix would occur, because of the relative difference in their permeabilities. Therefore, any releases to the surrounding groundwater-transport system from the surface of the shield berm must then be controlled by diffusion through the shield-berm matrix to its surface contact with transportable groundwater.

ORNL DWG 98C-300

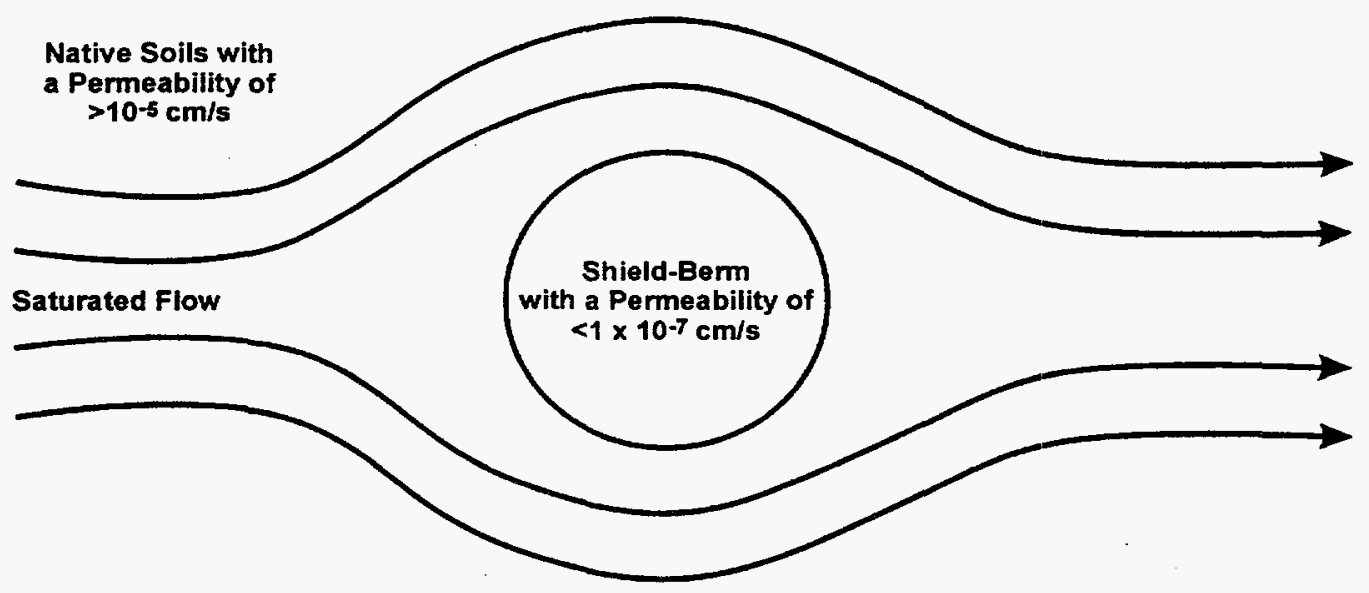

Fig. 2. If groundwater will flow around, rather than through, the shield berm matrix, releases will be diffusion controlled.

\subsection{DIFFUSION FROM SHIELD BERM WITH NO RETARDATION INTO THE SURROUNDING SOIL}

If all the nuclides are assumed to be available for transport within the shield-berm matrix, the individual rates of their diffusion will then depend on their interactions or partitioning constants between the berm's solid phases and the free water in the berm's pore structure. The mostcommon expression for this partitioning coefficient is $K_{M B}$, which expresses the relative amount of a contaminant species adsorbed/absorbed on a soil mineral versus the amount of contaminant dissolved in the free water in contact with the soil. Equation (1) defines the $K_{M B}$ used most often by researchers ${ }^{6}$ who measure these adsorption/absorption factors. The units of this definition of $K_{M B}$ are in milliliters per gram $(\mathrm{mL} / \mathrm{g})$ : 


$$
K_{M B}=\left[\frac{\left(\frac{\text { mole of species }}{\text { mass of porous solid }}\right)}{\left(\frac{\text { mole of species }}{\text { volume of liquid }}\right)}\right]
$$

The $K_{M B}$ is measured by taking a distilled aqueous solution with known initial concentrations of specific contaminants and mixing it with the known mass of soil particles to form an agitated slurry. After a few hours or days of equilibration, the solution is separated from the fine soil solids by filtering and/or centrifugation. The final concentrations of contaminants in the separated solution are measured, and the quantity adsorbed/absorbed is calculated by the difference between the initial and final concentrations.

The ubiquitous use of these static values of $K_{M B}$ to describe dynamic contaminant transport in groundwater systems is fraught with difficulty and misconceptions. First, using $K_{M B}$ as an equilibrium constant in dynamic transport models is very tenuous because of the short contact times widely used in $K_{M B}$ measurements. While ion exchange with the surfaces of the mineral phases plays an important role in the adsorption of contaminants, many important common minerals such as smectitic clays have even greater ion-exchange capacities in their internal structures. Since access to these internal ion-exchange sites is limited by slow absorption into these minerals, short-term tests do not always measure their potentially significant contribution to the retardation of contaminant transport. Also, in these measurements, other relatively slow mechanisms, such as coprecipitation, mineral component substitution, and secondary mineral formation, are not given enough time to influence the $K_{M B}$ results. When using only a simple partition coefficient, we cannot adequately describe the complex interactions that contaminants can have with soil components.

Furthermore, the measurement protocol itself has flaws. With fine-grained soils, particularly with silt and clay phases, the clean separation of the liquid from the soil slurry is very difficult. The silt and clay particles with high ion-exchange capacities form stubborn, stable colloids that can penetrate or blind most filters and prove very difficult to centrifuge. Since these soil colloids adsorb/absorb a relatively larger fraction of the cationic contaminants, a small contamination of the liquid phase by these soil colloids will strongly affect the analytical results. These colloids will dissolve, releasing their contaminants, during the acid-oxidation digestion step of the sample preparation for ion-coupled plasma or atomic adsorption analyses. 
Also, under the shear in this protocol's agitated slurry, the delicate, sometimes gossamer secondary mineral coatings on the soils' primary minerals are torn off, dispersed, and dissolved in the distilled water. These surface-alteration phases, which may include gelatinous hydrosilicate gels and mixed aluminosilicates, have high exchange capacities and can contribute greatly to the retardation of contaminant transport.

\subsubsection{Estimating the Retardation Factors and the Diffusion Coefficients}

First, $K_{M B}$ is used to define a retardation coefficient that is a ratio of a contaminant's velocity to that of the groundwater which carries it by advection through an open, porous soil. This simple model uses a dimensionless form of $K_{M B}$ as a formal partition coefficient $(K)$ between the stationary solids of the soils and the moving, free pore water. Because the contaminants are moving only when they are partitioned into the moving groundwater, $K$ is a measure of the relative amount of time that the contaminants spend on the sites' stationary soils or in their moving groundwaters. Equation (2) describes the dimensionless retardation factor $(R)$, and Eq. (3) defines $K$ in relationship to $K_{M B}$ :

$$
R=\left[\frac{1}{1+K}\right]
$$

in which

$$
K=\left[\frac{\left(\frac{\text { mole in species }}{\text { volume of solid phase }}\right)}{\left(\frac{\text { mole in species }}{\text { volume of liquid }}\right)}\right]=\left[\rho_{b} \cdot\left(\frac{1-\epsilon}{\epsilon}\right) \cdot K_{M B}\right] \text {, }
$$

where

$K=$ a dimensionless contaminant species partition coefficient between the pore water and soil-berm minerals; 
$\rho_{b}=$ bulk density of porous soil, $\mathrm{g} / \mathrm{cm}^{3}$;

$\epsilon=$ average open-pore void fraction (or effective porosity), dimensionless.

This concept of a retardation factor also applies to diffusion processes. In a general sense, a diffusion coefficient, or diffusivity, is a statistical entity describing the relative shift in random molecular movement relative to a concentration gradient within a fluid or solid. Therefore, an "effective diffusion coefficient" $\left(D_{e}\right)$ can legitimately be used to numerically summarize the collective result of simultaneous transport mechanisms in a complex matrix of soil minerals.

In the mineral matrixes of the shield berm, water is in at least four states. Some water is chemically bonded in the mineral structure as waters of hydration. Other (clathrate) water is captured within the crystals or trapped in the silica-alumina hydrogels at the mineral surfaces. Some water is adsorbed onto the mineral surfaces or constrained within the hydrodynamic boundary of the ionic double layers of the minerals. Finally, in the saturated, open pores, there is "free water." Without advection this pore water is stagnant. Within this stagnant, free water, the contaminants can diffuse from pore to pore and from higher to lower concentrations. The diffusion rates of contaminant species in this free water are controlled by the hydrodynamic radii

- of the ions with their hydration spheres. For this study, a representative diffusion rate in free water $\left(D_{f}\right)$ of $7 \times 10^{-6} \mathrm{~cm}^{2} / \mathrm{s}$ was chosen for all species.

As in the advection cases, the contaminants are partitioned between the free pore water and the surfaces of the berm minerals. Therefore, the retardation factor in Eq. (2) can also be used to estimate the reduction in the pore diffusion $\left(D_{j}\right)$ and to calculate an effective diffusion coefficient $\left(D_{e}\right)$, which is described in Eq. (4):

$$
D_{e}=\left[\frac{D_{f}}{1+K}\right] \text {, }
$$

where

$D_{e}=$ effective diffusion coefficient, $\mathrm{cm}^{2} / \mathrm{s}$;

$D_{f}=$ free diffusion coefficient of contaminant species within pore water, $\mathrm{cm}^{2} / \mathrm{s}$; (assuming a value for $D_{f}$ of $7 \times 10^{-6} \mathrm{~cm}^{2} / \mathrm{s}$ for all contaminants.);

$K=$ dimensionless contaminant species partition coefficient between pore water and soil-berm minerals [Eq. (3)]. 
In this study, the additional factor, tortuosity $(\tau)$, is also considered to affect the estimates of contaminants $D_{c}$. Tortuosity is the ratio of the length of the actual diffusion path to the surface divided by the shortest geometric distance to the surface. The soil-berm matrix is a tortuous diffusion labyrinth of diffusion detours around solid minerals. This labyrinth effectively creates obstructions in the direct path to the surface of the shield berm. In this study, the tortuosity was estimated to be 2 for the fine-grained, compacted, native-soil berm. The addition of the tortuosity factor and the full expansion of the definition of the effective diffusion coefficient result in Eq. (5):

$$
D_{e}=\left[\frac{D_{f}}{\tau^{2} \cdot\left[1+\rho_{b} \cdot\left[\frac{(1-\epsilon)}{\epsilon}\right] \cdot K_{M B}\right]}\right] \text {, }
$$

where

$\tau=$ tortuosity, dimensionless

(assuming that $\tau$ was equal to 2 for the fine, compacted berm soils.);

$\rho_{b}=$ bulk density of porous soil, $\mathrm{g} / \mathrm{cm}^{3}$;

$\epsilon=$ average open-pore void fraction, dimensionless.

Using measurements and estimates of $K_{M B}$ for the key isotopes in Table 1, the effective diffusion coefficients $\left(D_{e}\right)$ and the retardation factors $(R)$ were calculated using Eqs. (5) and (2), respectively. Table 3 summarizes the results of these calculations.

\subsubsection{Diffusion-Controlled Contaminant Releases from the Shield Berm}

Using the derived effective diffusion coefficient $\left(D_{e}\right)$ from the previous section, the following two diffusion models are applied to the SNS shield berm. The first, and simpler, semiinfinite-medium model is used to calculate the initial release rates up until about $20 \%$ of a specific containment is released. After that, the remaining releases to complete depletion are calculated using a "geometry-specific" model. 


\begin{tabular}{|c|c|c|c|}
\hline \multirow{2}{*}{\multicolumn{2}{|c|}{$\begin{array}{l}\text { Assumptions: } \\
\text { Berm density } \\
\text { Soil density } \\
\text { Compact porosity } \\
\text { Soil porosity }\end{array}$}} & \multirow{2}{*}{\multicolumn{2}{|c|}{$\begin{array}{ll}\text { Free-water diffusion, } D_{f} & =7.00 \mathrm{E}-06 \mathrm{~cm}^{2} / \mathrm{s} \\
\text { Soil tortuosity } & =2.0 \\
\text { Compact tortuosity } & =2.0\end{array}$}} \\
\hline & & & \\
\hline Isotope & $\begin{array}{l}\text { ORNL } K_{M B} \\
\quad(\mathrm{~mL} / \mathrm{g})\end{array}$ & $\begin{array}{c}D_{e} \text {, calculated } \\
\text { diffusion coefficients } \\
\left(\mathrm{cm}^{2} / \mathrm{s}\right)\end{array}$ & $\begin{array}{l}R, \text { calculated } \\
\text { retardation coefficients }\end{array}$ \\
\hline $\begin{array}{l}{ }^{3} \mathrm{H} \\
{ }^{10} \mathrm{Be} \\
{ }^{14} \mathrm{C} \\
{ }^{22} \mathrm{Na} \\
{ }^{26} \mathrm{Al} \\
{ }^{36} \mathrm{Cl} \\
{ }^{39} \mathrm{Ar} \\
{ }^{40} \mathrm{~K} \\
{ }^{41} \mathrm{Ca} \\
{ }^{53} \mathrm{Mn} \\
{ }^{54} \mathrm{Mn} \\
{ }^{55} \mathrm{Fe}\end{array}$ & $\begin{array}{r}0 \\
0 \\
10 \\
15 \\
3,000 \\
0 \\
0 \\
15 \\
3,000 \\
25 \\
25 \\
468,000\end{array}$ & $\begin{array}{l}1.750 \mathrm{E}-06 \\
1.750 \mathrm{E}-06 \\
3.097 \mathrm{E}-08 \\
2.077 \mathrm{E}-08 \\
1.051 \mathrm{E}-10 \\
1.750 \mathrm{E}-06 \\
1.750 \mathrm{E}-06 \\
2.077 \mathrm{E}-08 \\
1.051 \mathrm{E}-10 \\
1.237 \mathrm{E}-08 \\
1.237 \mathrm{E}-08 \\
6.738 \mathrm{E}-13\end{array}$ & $\begin{array}{l}1 \\
1 \\
2.410 \mathrm{E}-02 \\
1.619 \mathrm{E}-02 \\
8.230 \mathrm{E}-05 \\
1 \\
1 \\
1.619 \mathrm{E}-02 \\
8.230 \mathrm{E}-05 \\
9.665 \mathrm{E}-03 \\
9.665 \mathrm{E}-03 \\
5.276 \mathrm{E}-07\end{array}$ \\
\hline
\end{tabular}

\subsubsection{Semiinfinite-Medium Diffusion Model}

The initial diffusion-controlled release of contaminants from the shield berm is based on the source-term model shown in Eq. (6). As seen in this model, the surface-to-volume (S:V) ratio of the berm controls the "window" size of contaminant transport into the surrounding environment, and the effective $D_{e}$ controls the rate of transport from within the berm matrix. This general "semiinfinite-medium" equation ${ }^{8}$ describes an ever-decreasing release rate with time," as a depletion layer forms near the surface of the monolith. When the results of this model are compared with those of more complex geometric models, the calculations based on Eq. (6) represent an upper bound on the potential release of contaminants:

$$
F(t)=2\left[\frac{S}{V}\right] \cdot \sqrt{\frac{D_{e}}{\pi} \cdot t},
$$


where

$F(t)=$ fractional contaminant release with time, $t$

$S=$ berm surface area, $\mathrm{cm}^{2}$;

$V=$ berm volume, $\mathrm{cm}^{3}$;

$D_{e}=$ effective diffusion coefficient of contaminant, $\mathrm{cm}^{2} \mathrm{~s}^{-1}$.

This semiinfinite-medium model is accurate during the initial release scenario up to the loss of about $20 \%$ of the initial contaminant inventory from within the berm. At higher percentages of release, a geometry-specific model, such as Eq. (7), should be used.

\subsubsection{Geometry-Specific Diffusion Model}

For cases in this study in which more than $20 \%$ of the initial contaminant in the berm matrix is released during the period of interest, a second geometry-specific model is used [Eq. (7)]. This cylinder and sphere diffusion model must be used for many of these cases because (1) some of the values of $D_{e}$ are large $\left[>10^{-11} \mathrm{~cm}^{2} / \mathrm{s}\right.$ (see Table 3)], (2) the $\mathrm{S}: \mathrm{V}$ ratio of the berm is large $\left(0.192 \mathrm{~cm}^{-1}\right)$, and (3) the period of the analysis is sufficiently long in most cases to release over $20 \%$ of a specific contaminant.

$$
F(t)=\left[1-\frac{32}{\pi^{2} a^{2}}\right] \cdot \sum_{n=1}^{n} \sum_{m=1}^{m} \exp \left[\frac{-D e \cdot\left[\alpha_{m}^{2}+(2 n-1)^{2} \frac{\pi^{2}}{4 L^{2}}\right] \cdot t}{(2 n-1)^{2} \alpha_{m}^{2}}\right]
$$

where

$F(t)=$ fractional contaminant release with time, $t$

$a \quad=$ cylinder radius, $\mathrm{cm}$;

$D_{e}=$ effective diffusion coefficient, $\mathrm{cm}^{2} \mathrm{~s}^{-1}$

$\alpha_{m}=m$ th positive root of a zero-order Bessel function $\left[J_{0}(m)\right]$;

$L=$ cylinder half-height, $\mathrm{cm}$. 
This geometry-specific model describes the diffusion from cylinders ${ }^{10}$ and can be used successfully for approximated spheres' as well. This model results from Nestor's analytical solution ${ }^{10}$ in cylindrical coordinates. MathCad ${ }^{0}$ calculations using these models on proposed berm shielding for the SNS program are presented in the appendix to this report.

The application of these models severely overestimates the potential releases of the contaminants in Table 1. Based on conservative values of $K_{M B}$, these models assume the total availability of the nuclides for transport when many of them are trapped within the soil minerals. Also, these models assume that throughout the berm matrix, this system is always at equilibrium when intuitively the complex mechanisms of the contaminants' retention cannot be. Finally, because the activation products are not formed uniformly across the length and the radius of the berm, the assumption of a uniform distribution of contaminants within the shield berm at the end of the 30-year SNS operations cannot be possible. Therefore, if the conservative results of these analyses show that the calculated potential concentrations of contaminants are below the regulatory limits, there is a high level of confidence that it is true.

\subsection{SNS HYDROLOGICAL SETTING AND ASSUMPTIONS}

The proposed Oak Ridge, Tennessee, site for the SNS is in the Ridge and Valley physiographic province bordering the Cumberland Plateau. The rocks that form these ridges and soils were deposited some 300 million years ago. The proposed West Chestnut Ridge site on the ORR lies at an elevation of $740 \mathrm{ft}$ above sea level on the residuum of the Copper Ridge dolomite sequence of the Knox Group. The residuum is up to $98 \mathrm{ft}$ thick, and the saturated groundwater table lies 60 to $80 \mathrm{ft}$ below the site's surface. This study chose to consider a 33-ft- $(10-\mathrm{m}-)$ wide strip as an arbitrary "zone of influence" around the SNS tunnel and shield-berm system (see Fig. 3).

The climate is indicative of the humid southern Appalachian region, with annual rainfall amounts of 37 to $76 \mathrm{in}$. The local annual averages are in the range of 45 to $60 \mathrm{in}$. With corrections for runoff and transpiration, the estimated annual groundwater recharge on the proposed site is between 15 and 30 in. This study assumed that the lower end of this recharge range would minimize the dilution of the potential impacts of contaminant releases.

Forming the storm-flow zone, only the upper 1 to $2 \mathrm{~m}$ of soil saturates during heavy rain events, and $90 \%$ of the surface stream flow in this area comes from surface runoff and discharges

\footnotetext{
*A cylinder, a sphere, and a cube may be related if they have the same surface-to-volume ratio.
} 
from this thin layer of surface soils. Below $2 \mathrm{~m}$, this soil rarely becomes saturated. The proposed SNS beam-tunnel system is to be installed below this depth in the unsaturated vadose soil zone above the water table. Nevertheless, this study assumed that the berm's outer surface was continuously swept by moving water to maximize the potential impact of the contaminant diffusion. If contaminants at the surface are not removed, the subsequent contaminant buildups at the surface will come to equilibrium with the concentration gradients from within the berm and contaminant transport out of the berm will stop.

Figure 3 depicts the hydrologic cross section used to calculate the flux of precipitation from above and the flux of groundwater below a proposed Oak Ridge site. Assuming 10-m zones of influence beyond the $22.8-\mathrm{m}$ diam of the berm and assuming $15 \mathrm{in}$. of annual recharge, the cross section of the 958-m SNS tunnel system has an effective area of $41,860 \mathrm{~m}^{2}$ and an annual recharge volume of $15,950 \mathrm{~m}^{3} /$ year. The uncompacted soils have a porosity of 0.35 and a density of $1.35 \mathrm{~g} / \mathrm{cm}^{3}$. The mixing zone at the surface of the saturated groundwater table is assumed to be $3 \mathrm{~m}$ deep, and the groundwater velocity under this site is assumed to $2.9 \mathrm{~m} / \mathrm{year}$. Thus, the annual horizontal contribution to the flux of groundwater under the SNS tunnels is only $29,780 \mathrm{~m}^{3} /$ year. This brings the total annual water balance under the SNS facility and its $10-\mathrm{m}$ zones of influence to an annual turnover of $18,930 \mathrm{~m}^{3} /$ year. This turnover rate along with the calculated transport rates of the contaminants to the outer surface of the berm was used to calculate the dilution and potential concentrations of contaminants in the groundwater.

While published estimates of the hydraulic conductivity in the vadose zone when it is saturated are less than $0.2 \mathrm{~m} /$ year, ${ }^{11}$ this study chose to assume that it could be $1 \mathrm{~m} /$ year. If so, a packet of percolating water with contaminants from the berm's surface could reach the boundary of the $10-\mathrm{m}$ zone of influence in only 10 years. This also assumes that this near-field zone may be disturbed by construction activities and that there is no retardation of the migration of contaminants by partitioning with the native soils.

\subsection{DECAY OF ISOTOPES DURING DIFFUSION AND TRANSPORT}

These analyses applied isotopic decay factors to account for the radioactive decay of the contaminants in Table 1, starting at the end of the 30-year operation of the facility and estimated over the diffusion and migration travel times. This is an important factor for those isotopes with high specific activities and short half-lives. 


\section{Oak Ridge SNS Site Water Balance}

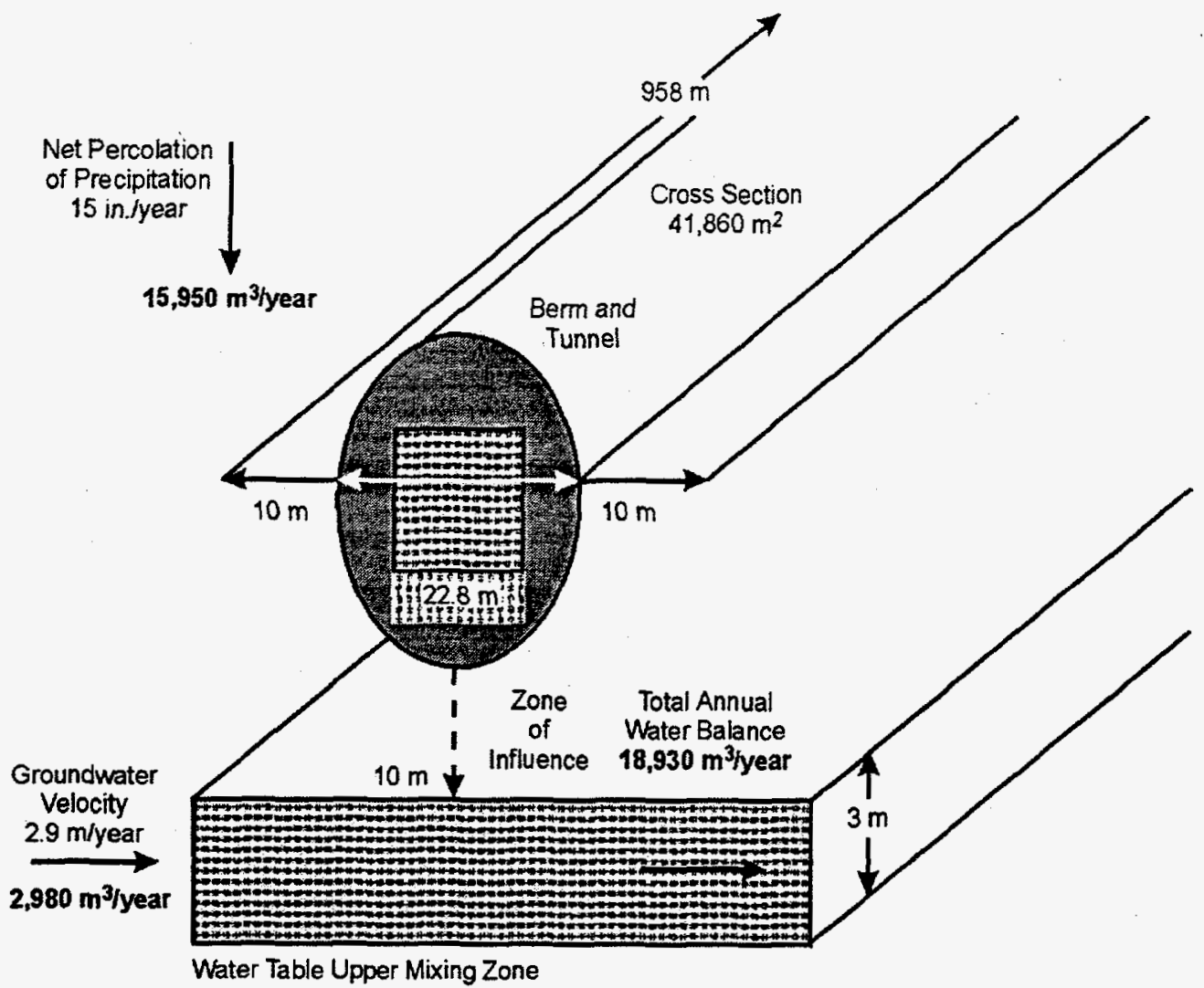

Fig. 3. Hydrologic cross section of the proposed SNS site used in the calculation of potential contaminant concentrations at the boundary of a $10-\mathrm{m}$ zone of influence.

\subsection{SUMMARY OF ASSUMPTIONS AND THEIR EFFECTS ON THE ANALYSES}

This section summarizes the assumptions used in this study and attempts to estimate their impact on the final analyses. The assumptions are as follows:

- Thirty years of continuous operations over a projected life of 40 years results in maximum credible concentration of activation products.

- The buildup of activation products remains stationary until the end of operations. 
- While the SNS facility is placed on a very thick, load-bearing concrete pad, the activation and transport analyses in Sects. 4 and 6 conservatively assume that the pad's thickness is the same as the tunnels' thinnest dimension.

- The shield berm is hydraulically connected to the local groundwater recharge and transport system.

- The activation rates are based on the highest-energy section of the SNS beam at $1 \mathrm{GeV}$.

- These highest activation levels are distributed over the entire length of the SNS beam system and have both linear and axial homogeneity.

- Because of the fine primary particle sizes in the compacted-soil shield berm, all activation products are immediately available for transport.

- There are no significant contributions of activation products from the load-bearing concrete tunnel structure.

- Continuous saturated flow occurs over the outer surface of the shield berm and continuously removes contaminants that diffuse to the surface and are carried to the water table below.

- Movement of contaminants within the berm is controlled by diffusion, which is estimated using a conservative self-diffusion coefficient $\left(D_{f}\right)$ and partition coefficient $\left(K_{M B}\right)$.

- The diffusion models used in this study imply that within the berm matrix the contaminants are instantaneously at equilibrium everywhere within the system (using $K_{M B}$ as an equilibrium constant).

- A representative diffusion rate in free water $\left(D_{f}\right)$ of $7 \times 10^{-6} \mathrm{~cm}^{2} / \mathrm{s}$ was chosen for all species.

- The tortuosity was estimated to be 2 for the compacted native-soil berm.

- The lower end of the recharge range was chosen in order to minimize the dilution of the potential impacts of contaminant releases and assumes that only about one-fourth of the annual precipitation reaches the water table and that there is no dilution by run-on to the SNS site.

- Travel times within the SNS berm's zone of influence are five times those expected for undisturbed native soils.

- The calculated nuclide concentrations are corrected for radioactive decay from the end of operations and over the contaminant travel times.

- There is no retardation of the contaminant transport in the native soils.

The net effect of this cascade of conservative assumptions throughout these analyses is to conservatively overestimate the potential concentrations in the groundwater below the SNS site. 
When the resulting predictions show that the nuclides are below NRC 10 CFR Part 20 DWLs, there is a very high confidence that those limits can never be exceeded during the postoperation period of the facility.

\section{RESULTS}

Sample calculations are presented in the appendix, and Table 4 summarizes the results of these assumptions and analyses. Table 5 compares these results with the current NRC and U.S. Department of Energy (DOE) groundwater guidelines. Since there are pilot studies under way to establish the efficacy of having the NRC regulate some DOE facilities, the NRC 10 CFR Part 20 standards may become the appropriate groundwater guidelines for the SNS facility. Therefore, while ${ }^{14} \mathrm{C}$ meets the DOE standard, it does not meet the potential future NRC standard.

Without considering the retardation of their migration by the native soils and with these severe assumptions, only 3 of these 12 isotopes have any potential for impacting the quality of the groundwater beyond the $10-\mathrm{m}$ zone of influence of the SNS facility.

In the cases of ${ }^{22} \mathrm{Na}$ and ${ }^{54} \mathrm{Mn}$, which have short half-lives of 2.6 years and 0.854 year, respectively, their retardation factors $(R)$ of $1.6 \times 10^{-2}$ and $9.7 \times 10^{-3}$ (Table 3 ), respectively, ensure that these isotope will decay to levels below concern before they can reach the $10-\mathrm{m}$ boundary. With retardation in the Oak Ridge native soils, the expected travel time would be about 625 and 1000 years, respectively.

In the case of ${ }^{14} \mathrm{C}$, which has a half-life of 5730 years and a retardation coefficient $(R)$ of $2.4 \times 10^{-2}$, retardation can increase the unretarded travel time of $10 \mathrm{~m}$ over 10 years in this site's soils to over 400 years. This increased travel time of 0.07 half-life will reduce the potential amount of ${ }^{14} \mathrm{C}$ by only $5 \%$. Even with the expected actual water migration rate of $0.2 \mathrm{~m} /$ year, the unretarded travel time would be 50 years and the retarded travel time could be as long as 2080 years. This longer travel time would result in a decay reduction in ${ }^{14} \mathrm{C}$ of about 0.36 half-life, which is only a $22 \%$ reduction. However, these increases in travel times would also allow an increase in the contaminant's potential dilution in the groundwater to between 5 and 208 times. 


\begin{tabular}{|c|c|c|c|c|c|}
\hline Isotope & $\begin{array}{c}\text { Half-life } \\
\text { (year) }\end{array}$ & $\begin{array}{c}\text { Total } \mathrm{Ci} \\
\text { within } 1 \mathrm{st} 4 \mathrm{~m} \\
\text { of berm shield } \\
\text { over } 958 \mathrm{~m}^{a}\end{array}$ & $\begin{array}{c}\text { Estimated } \\
\text { homogeneous } \\
\text { concentrations } \\
\text { in berm }(\mu \mathrm{Ci} / \mathrm{g})\end{array}$ & $\begin{array}{c}\text { Estimated } \\
\text { pore-water } \\
\text { concentrations } \\
\text { at } 10 \mathrm{~m} \text { after } \\
10 \text { years }\left(\mu \mathrm{Ci} / \mathrm{cm}^{3}\right)\end{array}$ & $\begin{array}{c}\text { NRC } \\
10 \text { CFR Part } 20 \\
\text { DWL }\left(\mu \mathrm{Ci} / \mathrm{cm}^{3}\right)\end{array}$ \\
\hline $\begin{array}{l}{ }^{3} \mathrm{H} \\
{ }^{10} \mathrm{Be} \\
{ }^{34} \mathrm{C} \\
{ }^{22} \mathrm{Na} \\
{ }^{26} \mathrm{Al} \\
{ }^{36} \mathrm{Cl} \\
{ }^{39} \mathrm{Ar} \\
{ }^{40} \mathrm{~K} \\
{ }^{41} \mathrm{Ca} \\
{ }^{53} \mathrm{Mn} \\
{ }^{54} \mathrm{Mn} \\
{ }^{55} \mathrm{Fe}\end{array}$ & $\begin{array}{l}1.23 E+01 \\
1.50 E+06 \\
5.73 E+03 \\
2.60 E+00 \\
7.15 E+05 \\
3.01 E+05 \\
2.69 E+02 \\
1.27 E+09 \\
1.03 E+05 \\
3.70 E+06 \\
8.54 E-01 \\
2.73 E+00\end{array}$ & $\begin{array}{l}2.278 E+08 \\
1.976 E-04 \\
1.546 E+02 \\
3.283 E+02 \\
2.202 E-01 \\
8.593 E-02 \\
3.795 E+02 \\
2.684 E-03 \\
8.448 E-01 \\
1.639 E-03 \\
2.861 E+05 \\
2.202 E+04\end{array}$ & $\begin{array}{l}4.66 \mathrm{E}-08 \\
4.04 \mathrm{E}-10 \\
3.16 \mathrm{E}-04 \\
6.72 \mathrm{E}-04 \\
4.50 \mathrm{E}-07 \\
1.76 \mathrm{E}-07 \\
7.76 \mathrm{E}-04 \\
5.48 \mathrm{E}-09 \\
1.73 \mathrm{E}-06 \\
3.35 \mathrm{E}-09 \\
5.85 \mathrm{E}-01 \\
4.50 \mathrm{E}-02\end{array}$ & $\begin{array}{l}6.85 \mathrm{E}-08 \\
1.04 \mathrm{E}-09 \\
4.43 \mathrm{E}-04 \\
5.54 \mathrm{E}-05 \\
4.58 \mathrm{E}-08 \\
4.54 \mathrm{E}-07 \\
2.00 \mathrm{E}-03 \\
6.50 \mathrm{E}-09 \\
1.76 \mathrm{E}-07 \\
3.14 \mathrm{E}-09 \\
1.64 \mathrm{E}-04 \\
1.09 \mathrm{E}-15\end{array}$ & $\begin{array}{l}1.00 \mathrm{E}-03 \\
3.00 \mathrm{E}-05 \\
3.00 \mathrm{E}-05 \\
6.00 \mathrm{E}-06 \\
6.00 \mathrm{E}-06 \\
2.00 \mathrm{E}-05 \\
4.00 \mathrm{E}-06 \\
7.00 \mathrm{E}-04 \\
3.00 \mathrm{E}-05 \\
1.00 \mathrm{E}-04\end{array}$ \\
\hline \multicolumn{2}{|l|}{ Total } & $3.09 \mathrm{E}+05$ & & & \\
\hline
\end{tabular}

${ }^{a}$ Data from Table 2, column 8.

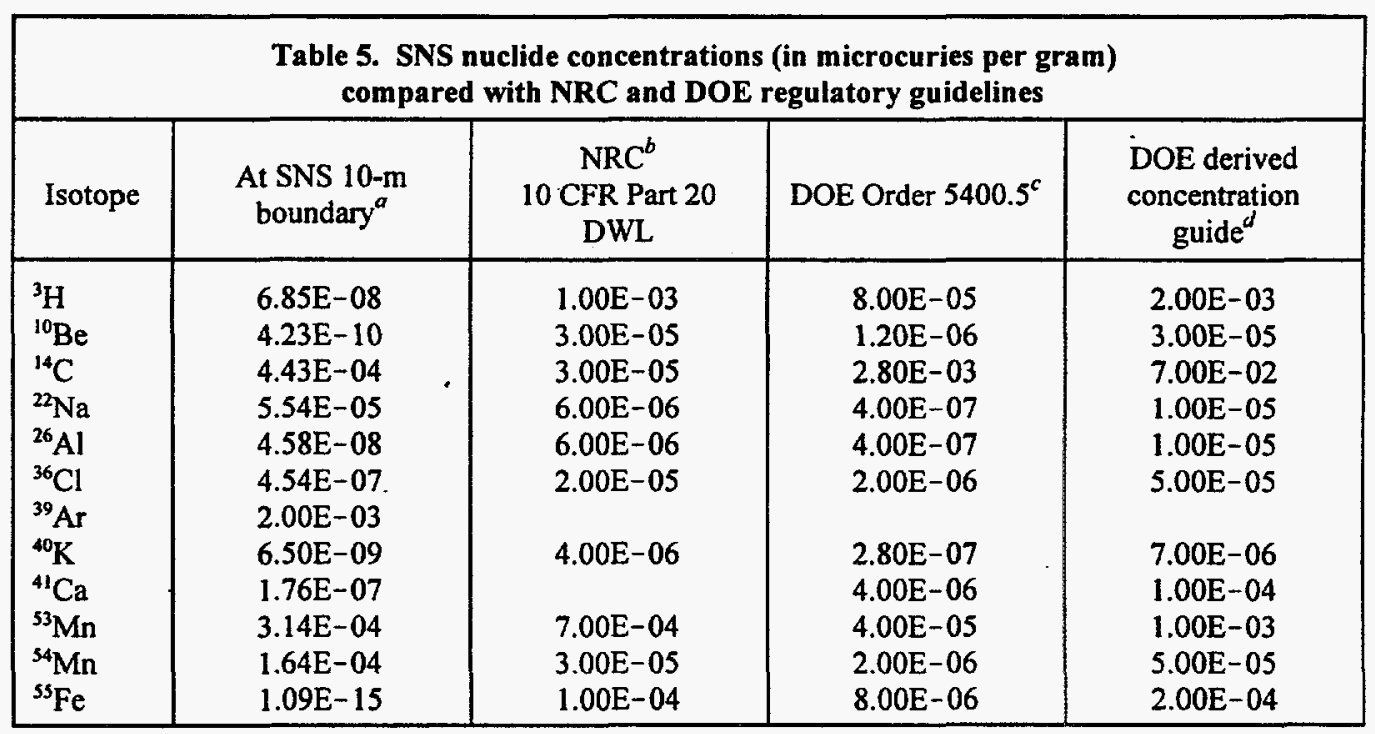

${ }^{o}$ Data from Table 4, column 5 .

${ }^{b}$ NRC 10 CFR Part 20, based on 50-mrem ingestion exposure.

'DOE Order 5400.5, "Drinking Water System," based on 4-mrem ingestion exposure-4\% of derived concentration guides (DCGs).

${ }^{c}$ DOE DCGs based on 100-mrem ingestion exposure. 
These results show that the only nuclide that could be of potential concern is ${ }^{14} \mathrm{C}$ because of its mobility, long half-life, and high specific activity. Nevertheless, these very conservative analyses show that it is unlikely that the NRC 10 CFR Part 20 DWLs will be exceeded for any of these activation products from a SNS shield berm made from compacted native soils on the ORR.

The following are recommendations to ensure that the conservative boundary conditions of these analyses are never approached in the actual "as-built" shield berm. Specific admixtures are also suggested as potential options to enhance the retention of ${ }^{14} \mathrm{C},{ }^{22} \mathrm{Na}$, and ${ }^{54} \mathrm{Mn}$ in the shield berm to ensure an increased margin of safety.

\section{RECOMMENDED DESIGN MODIFICATIONS AND SUGGESTED LABORATORY MEASUREMENTS}

These design recommendations are given in a graded approach from the easiest to implement to the more complex and expensive. The suggested laboratory measurements, using site-specific materials, are to confirm the conservatism of these analyses and to verify the key transport parameters for the 12 activation products of interest.

\subsection{RECOMMENDED SHIELD-BERM MODIFICATIONS}

These shield-berm design modifications include (1) introduction of a "capillary break" to disconnect the outer surface of the shield berm from the local hydraulic transport system, (2) chemical additions to the berm matrix to immobilize specific activation products, and (3) a concentric combination of coarse limestone, fine compacted clay, and coarse limestone. The first two recommendations are essentially needed modifications to the current SNS shield-berm design and address specific potential problems with ${ }^{14} \mathrm{C},{ }^{22} \mathrm{Na}$, and ${ }^{54} \mathrm{Mn}$. The third recommendation suggests a redesign of the shield berm to encompass functional criteria that were not in the original concept.

\subsubsection{Crushed Limestone Capillary Break To Isolate Berm from Local Hydrology}

Because water transport within the vadose zone is controlled by the size of the fine capillary pores of the soils, the outer surface of the shield berm can be "effectively" disconnected from the surrounding hydrologic transport system by inserting a layer of coarse, crushed limestone. Protected from the infiltration of fine particles by geomembranes, a coarse limestone layer forms 
a "capillary break." Any water recharge to the water table traveling through the vadose zone will then "wick" through the fine native soils and around the outside of this coarser layer.

Consequently, this recharge water can never touch the outer surface of the shield berm and there can be no transport of activation products through the vadose zone to the water table.

This simple, inexpensive modification also protects the shield berm from root intrusion, because root buds will follow the moisture that surrounds the SNS berm. Burrowing animals are also thwarted by the difficulty of digging in this coarse limestone barrier. Furthermore, the coarse limestone barrier can also protect the integrity of the shield berm by reducing erosion of the berm matrix during a site flooding from a surface run-on scenario.

Using standard construction practices for storm-runoff drains, this modification is easy to install and requires little maintenance. It is very effective and ensures hydrologic isolation of the SNS shield berm for decades.

\subsubsection{Calcium Hydroxide Berm Additive for ${ }^{14} \mathrm{C}$ Retention}

These analyses have shown that ${ }^{14} \mathrm{C}$ is the principal activation product of potential concern, probably because of the low $K_{M B}$ of 10 (Table 3 ) that was estimated for this nuclide. Because there are several mechanisms by which carbon can be sequestered in the berm and native soils, this low partition coefficient is intuitively very conservative. Nevertheless, there is a simple way to enhance the retention of ${ }^{14} \mathrm{C}$ in the shield-berm matrix.

Because carbon is most likely transported as either carbon dioxide $\left(\mathrm{CO}_{2}\right)$ or the bicarbonate anion $\left(\mathrm{HCO}_{3}{ }^{-}\right)$, simply adding a strong base to the matrix can bind these species in insoluble minerals. An inexpensive and readily available choice is calcium hydroxide $\left[\mathrm{Ca}(\mathrm{OH})_{2}\right]$. The addition of calcium hydroxide to the berm matrix would result in the following reaction:

$$
\mathrm{Ca}(\mathrm{OH})_{2}+\mathrm{CO}_{2}-\mathrm{CaCO}_{3}+\mathrm{H}_{2} \mathrm{O}
$$

This reaction would capture ${ }^{14} \mathrm{C}$ in the insoluble mineral, limestone $\left(\mathrm{CaCO}_{3}\right)$, and would increase its effective $K_{M B}$ in the shield-berm matrix. This addition would ensure that ${ }^{14} \mathrm{C}$ could not exceed the DWLs, even under the severe transport assumptions used in this analysis.

Equation (8) shows the natural "carbonization" of hydrated lime. The water is already in the hydrated lime [also known as "slaked lime" and "chicken lime" (Southern colloquial)]. Below grade, the pore spaces are at a relative humidity that is determined by the finest pore radii of the 
fine soils. Therefore, water vapor is saturated only within the finest pores of the compacted clay or surrounding soil. Also, in construction, the moisture content of the clay is adjusted to achieve optimum Proctor densities and low permeabilities. In addition, the concrete already has a relatively large inventory of $\mathrm{Ca}(\mathrm{OH})_{2}$ (portlandite) as a by-product of the cement reactions and has excess pore water from the tempered concrete mix. None of this water is free flowing. It is either bound as crystal water or trapped as pore water.

Calcium hydroxide could be introduced to the SNS shield-berm matrix by mixing it with either "slaked lime" $\left[\mathrm{Ca}(\mathrm{OH})_{2}\right]$ or "quick lime" $(\mathrm{CaO})$. Because they are strong bases, both materials are hazardous for workers to handle in the field; the latter is much more hazardous than the former. Nevertheless, they are common agricultural chemicals.

The fine compacted clay is from a sodium montmorillonite formation that has been in equilibrium within the thermodynamic stability field associated with its sodium-alumina-silica composition over geological time. By adding calcium and silica, the equilibrium is tipped toward forming phases through slow metamorphism that sequesters the sodium and manganese cations more effectively. It does not take much silica and/or calcium to effect this process for these trace elements.

The minimum constraints the amounts of the silica and calcium additive of affecting homogeneous mixtures with undesiccated materials of different textures depends on the rigor of the mixing technologies to be used. For example, the blending train at the ORR Hydrofracture Facility could achieve excellent homogeneity with minimum additions of 8 to $10 \mathrm{wt} \%$ of fly ash to clay, but using a backhoe and a roll-off box to mix these relatively dry materials would require a minimum addition of 14 to $16 \mathrm{wt} \%$ of fly ash. Since water is to be added in order to compact the clay, less expensive "conditioned" fly ashes with moisture contents as high as $18 \mathrm{wt} \%$ could be used in these blends. This would require as much as $20 \mathrm{wt} \%$ as a minimum addition of conditioned fly ash. These choices are driven by economic trade-offs between ease of mixing, process rate requirements, equipment availability, and costs.

\subsubsection{Berm Additive for ${ }^{22} \mathrm{Na}$ and ${ }^{54} \mathrm{Mn}$ Retention (Amorphous Silica)}

While these analyses showed that it is very unlikely that the short-lived nuclides ${ }^{22} \mathrm{Na}$ and

${ }^{54} \mathrm{Mn}$ could ever exceed the DWLs, there are inexpensive, readily available additives that could significantly increase the retention of all alkali and transition metals in the berm matrix. For 
example, the addition of reactive amorphous silica $\left(\mathrm{SiO}_{2}\right)$ in the presence of calcium hydroxide and clay minerals results in the formation of insoluble calcium alumina hydrosilicates, which are then extremely effective in sequestering alkali and transition metals. This addition could increase the effective $K_{M B}$ values of these metals by two or more orders of magnitude.

The least expensive sources of reactive silica pozzolans are fly ashes. In the western United States, the most prevalent sources are American Society of Testing and Materials (ASTM) Class $\mathrm{C}$ fly ash, which comes with $\mathrm{CaO}$ already in it. In the eastern United States, there is ASTM Class $\mathrm{F}$ fly ash with very low levels of $\mathrm{CaO}$. Oak Ridge lies in the power-generation system of the Tennessee Valley Authority, which has generated high quantities of high-quality Class F fly ash. These can be delivered at a cost of $\$ 8$ to $\$ 12 /$ ton. Other potential sources are volcanic pumice, diatomaceous earth, and burnt rice hulls. These sources can be much more expensive.

The blending constraints for the limes also hold true for these silicas. However, some silicas are much easier to mix and are sometimes added to facilitate the mixing of more difficult fine-solid materials. The silica-addition option should be considered only if the SNS construction plan has already committed to a berm-matrix, material-blending operation. Then the costs of adding the handling and blending complexity of a third component should be compared with the potential benefits of improving the retention of ${ }^{22} \mathrm{Na}$ and ${ }^{54} \mathrm{Mn}$.

\subsubsection{Concentric Combination of Coarse Limestone and Compacted Clays}

The previous recommended options are intended as "fixes" to the current SNS shield-berm design. However, this recommendation (a concentric combination of coarse limestone and compacted clays) suggests a different design approach, which encompasses a significantly broader range of functional criteria.

The intent of this recommendation is to construct the shield berm from the onset as if the SNS facility were to become a long-term, shallow-land-burial (SLB) site. While this approach increases the initial construction costs of the SNS facility by as much as $\$ 20-22$ million in year-2000 dollars, the reductions in overall life-cycle costs with regard to future facility decommissioning with year-2050 dollars could greatly outweigh the initial investment.

This recommendation takes advantage of our current knowledge of materials and applies our best construction practices for multiple engineered barriers to contaminant migration from SLB sites. This approach is summarized in Fig. 4, which depicts the proposed multibarrier system.

Note that common sand is quartz, a crystalline, unreactive form of $\mathrm{SiO}_{2}$. 
This approach has several advantages:

- results in uniform and predictable shielding, leaching, and migration characteristics for all the proposed sites;

- effects a defense in depth with multiple shielding, mechanical, and hydraulic barriers;

- applies common construction materials and construction practices that are applicable to all the proposed sites;

- has long-term stability with low maintenance;

- allows monitoring, collection, and treatment of potential contaminant migration; and

- may facilitate public acceptance of the SNS facility.

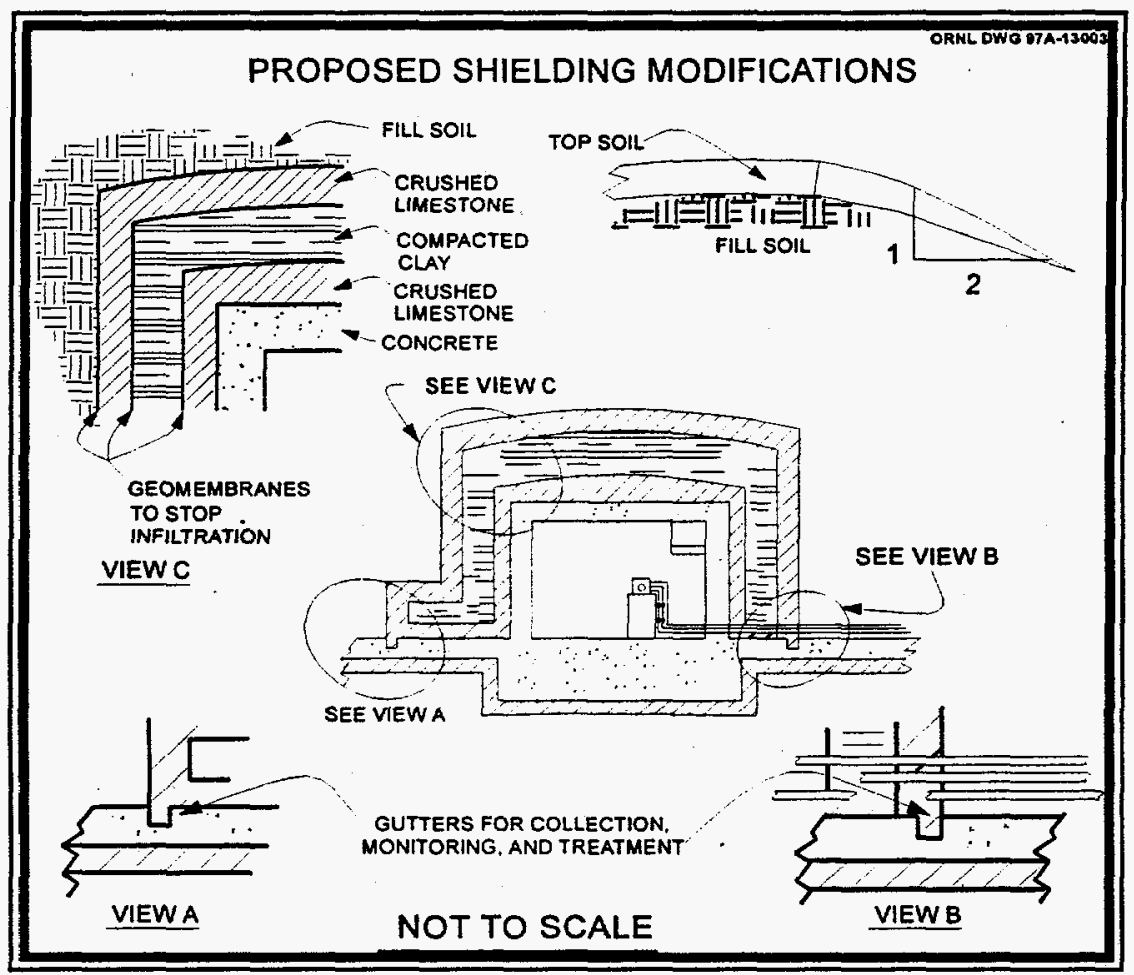

Fig. 4. Details of the proposed concentric-barriers concept for the shield berm of the 1-GeV SNS facility.

This design, as well as all of the others, uses a thick, reinforced, load-bearing pad to support the SNS tunnel structures and their beam apparatuses. The extra thickness of this concrete pad 
greatly reduces the formation of activation products in the coarse limestone and native soil below it. For conservatism in the previous activation and transport analyses in Sects. 4, 5, and 6, the concrete pad's thickness was assumed to be the same as the concrete tunnels' thinnest dimension.

Summarized in Fig. 4, this approach alternates layers of coarse- and fine-grained materials to effect multiple barriers to the hydraulic advection and migration of contaminants from the zone of irradiated shielding closest to the outside surface of the structural concrete of the accelerator tunnel. These same alternating coarse- and fine-grained barriers result in alternating layers that are mechanically semirigid and plastic. This condition then mitigates the propagation of mechanical forces through the barrier system whether from without or within the SNS tunnel structures.

The coarse material to be used in this shield system is common crushed limestone riprap. Going from the surface of the accelerator tunnel outward, the innermost, coarse, crushed limestone may be gap graded to achieve an average packing density of at least a $50 \%$ theoretical limestone density $\left(\approx 2.7 \mathrm{~g} / \mathrm{cm}^{3}\right)$ adjacent to the concrete accelerator tunnel. The thickness of the inner, coarse shield barrier is to be determined by shielding calculations, by ease of construction, and by considering that most of the activation products are formed closest to the beam within the first 2 to $3 \mathrm{~m}$.

Since these induced radioactive activation products are distributed throughout the mineral phases, this minimizes the $\mathrm{S}: \mathrm{V}$ ratio in this coarse inner shielding. By maximizing the size of this crushed limestone, the fraction of contaminants that is available for transport to the biosphere will be minimized. Because the transport of the contaminants from within the limestone to its surface is controlled by solid-state diffusion, the rates at which the radioactive isotopes could be available for transport are several orders of magnitude less than the isotopic decay rates. Therefore, the radioactivity simply decays completely before it can reach the surface of the limestone.

The coarse inner limestone is primarily for neutron shielding with the additional characteristic of sequestering up to $99.99 \%$ of the activation products outside the tunnel walls. The coarse limestone also has the capacity to hold these activation products until they decay in 3000 to 5000 years. In addition, it serves a secondary function as a redundant capillary break, preventing leaching of the activation products that form within the concrete of the tunnels themselves.

On the ORR, significant amounts of water are anticipated because of potential heavy rains and sheet flow off the land's surface above the SNS site. Under normal conditions, the actual 
percolation through the soils around the SNS tunnels is expected to be relatively low. Under upset conditions to the runoff diversion trenches or infiltration of fines into the outer capillary break, the inner limestone could be an important redundant barrier.

The next soft, impermeable layer of compacted clay hydraulically isolates the inner layer of coarse limestone, thus disconnecting it from the local surrounding hydrogeology. This barrier ensures that no transport can occur, even if a contaminant could make its way to the surface of the inner limestone riprap. It is standard shallow-land-disposal (SLD) technology to compact sodium bentonite to a darcy permeability of less than $10^{-7} \mathrm{~cm} / \mathrm{s}$. Then, relative to the surrounding native soils, which are greater than $10^{-5}$ darcy, there can be no effective advective transport of surface or groundwater through this clay hydraulic barrier to the inner shielding and accelerator tunnel (see Fig. 2, Sect. 5.2).

Using well-established principles in waste-burial technology, a second layer of coarse limestone not only mechanically protects the compacted clay layer from burrowing animals and root intrusion but also hydraulically disconnects the compacted clay layer from the transport of moisture in the surrounding native soil. Moisture transport in unsaturated soils or vadose zones is controlled by the capillary wicking through the fine pores. After inserting a coarse layer with a very large pore structure, the transport of water by percolation or transpiration will bypass this shielding system. Water can travel only through the capillary pores of the native soil and thus not be able to jump the coarse capillary break afforded by this outer layer of coarse stone. Therefore, this system of crushed stone and compacted clay effects double mechanical and hydraulic isolations of the inner shielding layer.

To ensure the long-term durability and to aid in the construction of these layered barriers, a geofabric is placed at the interfaces of the coarse stone with the native soils and compacted clay. This fabric reduces the infiltration of the fine soils and clay into the large pores of the crushed stone and results in a passive, multiple-barrier system that requires very little maintenance.

Finally, should infiltration occur, this system is constructed on a reinforced concrete pad into which leachate collection gutters are formed to collect, monitor, and treat any unexpected leachate.

The inner and outer coarse limestones are connected in order to deal with a transient localized flood from a breach in the cap in a catastrophic erosion scenario or some undiscovered long-term leak in the cooling system inside the tunnels. This connection allows a saturated plug of water to quickly pass out of the inner limestone. This system minimizes the contact time and the potential for leaching of the tunnel walls and the inner limestone surfaces. The short contact 
times, infinitesimal diffusion-controlled releases, and the high dilutions will still result in acceptable activity levels in the groundwater.

In principle, these thicknesses of the limestone and clay layers will be determined more by the neutron-shielding requirements and the practicality of construction rather than by hydraulic considerations. The configurations tested in these shielding calculations seem to satisfy both shielding requirements for the minimum thicknesses $(1.5$ to $3 \mathrm{~m})$ that one can reliably install around the rectangular SNS tunnels. With the vertical walls of the tunnels, the slump angles of the loose limestone and clay will not allow the shield to be constructed exactly as in the preliminary design in Fig. 4. Experienced construction experts will determine the actual final configurations of the layers and their volumes.

\subsubsection{Case Studies of Concentric Combinations of Limestone and Compacted Clays}

Two concentric shielding configurations were analyzed using the same activation model as that described in Sect. 3 to estimate the concentrations of long-lived activation products within the SNS shield berm. In these two cases, which are described in Table 6, the thicknesses of the . limestone and clay layers shown in Fig. 4 were varied from 1.5 to $3 \mathrm{~m}$.

\begin{tabular}{|c|c|c|c|c|c|}
\hline \multicolumn{5}{|c|}{ Table 6. Summary of two concentric shielding configuration case studies } \\
\hline Case & $\begin{array}{c}\text { Concrete } \\
\text { thickness } \\
(\mathrm{m})\end{array}$ & $\begin{array}{c}\text { Inner } \\
\text { limestone } \\
\text { thickness } \\
(\mathrm{m})\end{array}$ & $\begin{array}{c}\text { Compacted } \\
\text { clay } \\
\text { thickness } \\
(\mathrm{m})\end{array}$ & $\begin{array}{c}\text { Outer } \\
\text { limestone } \\
\text { thickness } \\
(\mathrm{m})\end{array}$ & $\begin{array}{c}\text { Soil zone } \\
\text { thickness } \\
(\mathrm{m})\end{array}$ \\
\hline 1 & 0.457 & 2 & 1.5 & 1.5 & 3.5 \\
\hline 2 & 0.457 & 3 & 2.0 & 2.0 & 1.5 \\
\hline
\end{tabular}

\subsubsection{Estimates of Activation Products Formed in the Concentric Shield}

The conservative estimates of the activation products formed in the proposed concentric shield were performed by Jeff Johnson of ORNL (Jeff Johnson, Computational Physics and Engineering, personal communication to Les Dole, Chemical Technology Division, ORNL) and are based on calculations using the worst-case beam leakage at the high-energy end of the Linac beam, which has $1 \mathrm{MW}$ of protons at $1 \mathrm{GeV}$. His calculations used a reference soil as the model for predicting the activation products and their quantities. The activation rates are based on 
projected particle leakage from the highest-energy section of the 1-MW beam at $1 \mathrm{GeV}$ and are characteristic of the last $20 \mathrm{~m}$ of the 493-m-long Linac accelerator, the beam storage ring, and the beam transfer tunnels.

This study of two cases conservatively assumed that these highest amounts of activation products (in curies) were distributed over the entire length of the accelerator facility's beam tunnel with both axial and linear homogeneity. For the longer-half-lived nuclides (with half-lives 21 year), the calculated results for the last $20 \mathrm{~m}$ are summarized in Tables 7 and 8 . Because the total SNS beam-tunnel system is $958 \mathrm{~m}$ long, multiplying the $20-\mathrm{m}$ quantities in the next-to-last column of Tables 7 and 8 by 47.9 extrapolates these worst-case quantities over the entire length of the accelerator facility (Tables 9 and 10, last column).

In case 1 , an estimated $4.76 \times 10^{5} \mathrm{Ci}$ is formed throughout the entire concentric shield. While this is slightly greater than the $3.09 \times 10^{5} \mathrm{Ci}$ formed in the soil berm, as shown in Table 2, there is no significant activity in the outer limestone and surrounding soil. Beyond contact with the site hydrology, $99.999 \%$ of the activity is contained within the inner limestone and compacted clay. This configuration affords a very high level of isolation for the activation products.

Table 7. Case 1: Conservative estimates of the concentrations (in curies) of long-lived nuclides for case 1 formed after 30 years of Linac operation in the last $20 \mathrm{~m}$ of the highest beam energy with $1 \mathrm{MW}$ of protons at $1 \mathrm{GeV}$ extrapolated over the entire 958-m length of the SNS beam tunnel system (47.9 times)

\begin{tabular}{|c|c|c|c|c|c|c|c|}
\hline Isotope & Concrete & $\begin{array}{c}\text { Inner } \\
\text { limestone } 1\end{array}$ & $\begin{array}{l}\text { Compacted } \\
\text { clay }\end{array}$ & $\begin{array}{c}\text { Outer } \\
\text { limestone } 2\end{array}$ & Soil zone & $\begin{array}{c}\text { Total within } \\
20 \mathrm{~m} \text { at } \\
1 \mathrm{MW} \\
\text { of } 1 \mathrm{GeV} \\
\text { protons }\end{array}$ & $\begin{array}{l}\text { Total over } \\
958 \mathrm{~m} \text { of } \\
\text { concentric } \\
\text { shield }\end{array}$ \\
\hline $\begin{array}{l}{ }^{3} \mathrm{H} \\
{ }^{10} \mathrm{Be} \\
{ }^{14} \mathrm{C} \\
{ }^{22} \mathrm{Na} \\
{ }^{26} \mathrm{Al} \\
{ }^{36} \mathrm{Cl} \\
{ }^{39} \mathrm{Ar} \\
{ }^{42} \mathrm{Ar} \\
{ }^{40} \mathrm{~K} \\
{ }^{41} \mathrm{Ca} \\
{ }^{53} \mathrm{Mn} \\
{ }^{54} \mathrm{Mn} \\
{ }^{55} \mathrm{Fe} \\
\end{array}$ & $\begin{array}{l}2.03 E+03 \\
6.32 E-04 \\
1.14 E+01 \\
2.34 E+03 \\
3.76 E-01 \\
1.02 E-01 \\
3.64 E+01 \\
1.58 E+00 \\
3.86 E-05 \\
5.35 E-02 \\
1.86 E-03 \\
9.75 E+04 \\
5.15 E+02 \\
\end{array}$ & $\begin{array}{l}6.47 \mathrm{E}+02 \\
6.11 \mathrm{E}-03 \\
5.71 \mathrm{E}+00 \\
1.06 \mathrm{E}+03 \\
4.93 \mathrm{E}-03 \\
1.37 \mathrm{E}-01 \\
1.98 \mathrm{E}+01 \\
3.95 \mathrm{E}+00 \\
3.63 \mathrm{E}-05 \\
4.76 \mathrm{E}-02 \\
1.71 \mathrm{E}-04 \\
6.91 \mathrm{E}+03 \\
3.59 \mathrm{E}+01 \\
\end{array}$ & $\begin{array}{c}4.09 \mathrm{E}+00 \\
0^{\alpha} \\
1.29 \mathrm{E}-02 \\
1.03 \mathrm{E}+01 \\
9.46 \mathrm{E}-04 \\
3.72 \mathrm{E}-07 \\
2.70 \mathrm{E}-03 \\
0^{a} \\
3.10 \mathrm{E}-08 \\
2.55 \mathrm{E}-06 \\
4.89 \mathrm{E}-08 \\
1.24 \mathrm{E}+03 \\
9.19 \mathrm{E}-02 \\
\end{array}$ & $\begin{array}{c}3.10 \mathrm{E}-02 \\
4.08 \mathrm{E}-09 \\
6.12 \mathrm{E}-03 \\
1.95 \mathrm{E}-03 \\
0^{a} \\
0^{a} \\
4.22 \mathrm{E}-04 \\
0^{a} \\
4.82 \mathrm{E}-09 \\
6.11 \mathrm{E}-06 \\
0^{a} \\
0^{a} \\
3.24 \mathrm{E}-04 \\
\end{array}$ & $\begin{array}{l}0^{a} \\
0^{a} \\
0^{a} \\
0^{a} \\
0^{a} \\
0^{a} \\
0^{a} \\
0^{a} \\
0^{a} \\
0^{a} \\
0^{a} \\
0^{a} \\
0^{a} \\
\end{array}$ & $\begin{array}{l}6.51 \mathrm{E}+02 \\
6.11 \mathrm{E}-03 \\
5.73 \mathrm{E}+00 \\
1.07 \mathrm{E}+03 \\
5.88 \mathrm{E}-03 \\
1.37 \mathrm{E}-01 \\
1.98 \mathrm{E}+01 \\
3.95 \mathrm{E}+00 \\
3.64 \mathrm{E}-05 \\
4.76 \mathrm{E}-02 \\
1.71 \mathrm{E}-04 \\
8.15 \mathrm{E}+03 \\
3.60 \mathrm{E}+01 \\
\end{array}$ & $\begin{array}{l}3.12 \mathrm{E}+04 \\
2.92 \mathrm{E}-01 \\
2.75 \mathrm{E}+02 \\
5.11 \mathrm{E}+04 \\
2.82 \mathrm{E}-01 \\
6.55 \mathrm{E}+00 \\
9.49 \mathrm{E}+02 \\
1.89 \mathrm{E}+02 \\
1.74 \mathrm{E}-03 \\
2.28 \mathrm{E}+00 \\
8.20 \mathrm{E}-03 \\
3.90 \mathrm{E}+05 \\
1.72 \mathrm{E}+03 \\
\end{array}$ \\
\hline Total & $1.02 \mathrm{E}+05$ & $8.68 \mathrm{E}+03$ & $1.26 \mathrm{E}+03$ & $3.99 \mathrm{E}-02$ & $0^{a}$ & $9.94 \mathrm{E}+03$ & $4.76 E+05$ \\
\hline Percent & 91.158 & 7.722 & 1.120 & 0.000 & 0.000 & \multicolumn{2}{|c|}{$\begin{array}{l}\text { Distribution between concrete } \\
\text { and shield }\end{array}$} \\
\hline Percent & & 87.333 & 12.666 & 0.000 & 0.000 & \multicolumn{2}{|c|}{ Distribution in shield layers } \\
\hline
\end{tabular}

${ }^{\circ} 0=$ less than $1 E-9$ 
In case 2 , an estimated $3.65 \times 10^{5} \mathrm{Ci}$ is formed throughout the entire concentric shield. This is approximately the same as the $3.09 \times 10^{5} \mathrm{Ci}$ formed in the soil berm, as shown in Table 2, within the accuracy of these calculations. Again, there is no activity in the outer limestone and surrounding soil. Well beyond any contact with the site's hydrology, $99.99 \%$ of the activation products are contained within the inner limestone. Less than $0.01 \%$ is contained in the compacted clay. This configuration ensures the highest level of isolation for the activation products. The percentages of activation products contained within the inner limestone are 87.333 and 99.99 for cases 1 and 2, respectively.

\begin{tabular}{|c|c|c|c|c|c|c|c|}
\hline Isotope & Concrete & $\begin{array}{c}\text { Inner } \\
\text { limestone } 1\end{array}$ & $\begin{array}{l}\text { Compacted } \\
\text { clay }\end{array}$ & $\begin{array}{c}\text { Outer } \\
\text { limestone } 2\end{array}$ & Soil zone & $\begin{array}{l}\text { Total within } \\
\text { shield } 20 \mathrm{~m} \\
\text { at } 1 \mathrm{MW} \\
\text { of } 1 \mathrm{GeV} \\
\text { protons }\end{array}$ & $\begin{array}{l}\text { Total over } \\
958 \mathrm{~m} \text { of } \\
\text { concentric } \\
\text { shield }\end{array}$ \\
\hline $\begin{array}{l}{ }^{3} \mathrm{H} \\
{ }^{10} \mathrm{Be} \\
{ }^{14} \mathrm{C} \\
{ }^{22} \mathrm{Na} \\
{ }^{26} \mathrm{Al} \\
{ }^{36} \mathrm{Cl} \\
{ }^{39} \mathrm{Ar} \\
{ }^{42} \mathrm{Ar} \\
{ }^{40} \mathrm{~K} \\
{ }^{41} \mathrm{Ca} \\
{ }^{53} \mathrm{Mn} \\
{ }^{54} \mathrm{Mn} \\
{ }^{55} \mathrm{Fe}\end{array}$ & $\begin{array}{l}1.94 E+03 \\
4.51 E-04 \\
1.11 E+01 \\
2.50 E+03 \\
3.86 E-01 \\
9.81 E-02 \\
3.79 E+01 \\
7.26 E-04 \\
3.80 E-05 \\
5.04 E-02 \\
1.81 E-03 \\
8.59 E+04 \\
4.44 E+02\end{array}$ & $\begin{array}{l}6.47 E+02 \\
6.11 E-03 \\
5.71 E+00 \\
1.06 E+03 \\
4.93 E-03 \\
1.37 E-01 \\
1.98 E+01 \\
3.95 E+00 \\
3.63 E-05 \\
4.76 E-02 \\
1.71 E-04 \\
6.91 E+03 \\
3.59 E+01\end{array}$ & $\begin{array}{c}4.09 \mathrm{E}+00 \\
0^{\alpha} \\
1.29 \mathrm{E}-02 \\
1.03 \mathrm{E}+01 \\
9.46 \mathrm{E}-04 \\
3.72 \mathrm{E}-07 \\
2.70 \mathrm{E}-03 \\
0^{a} \\
3.10 \mathrm{E}-08 \\
2.55 \mathrm{E}-06 \\
4.89 \mathrm{E}-08 \\
1.24 \mathrm{E}+03 \\
9.19 \mathrm{E}-02\end{array}$ & $\begin{array}{l}0^{a} \\
0^{a} \\
0^{a} \\
0^{a} \\
0^{a} \\
0^{a} \\
0^{a} \\
0^{a} \\
0^{a} \\
0^{a} \\
0^{a} \\
0^{a} \\
0^{a}\end{array}$ & $\begin{array}{l}0^{a} \\
0^{a} \\
0^{a} \\
0^{a} \\
0^{a} \\
0^{a} \\
0^{a} \\
0^{a} \\
0^{a} \\
0^{a} \\
0^{a} \\
0^{a} \\
0^{a}\end{array}$ & $\begin{array}{l}6.51 \mathrm{E}+02 \\
6.11 \mathrm{E}-03 \\
5.73 \mathrm{E}+00 \\
1.07 \mathrm{E}+03 \\
5.88 \mathrm{E}-03 \\
1.37 \mathrm{E}-01 \\
1.98 \mathrm{E}+01 \\
3.95 \mathrm{E}+00 \\
3.64 \mathrm{E}-05 \\
4.76 \mathrm{E}-02 \\
1.71 \mathrm{E}-04 \\
8.15 \mathrm{E}+03 \\
3.60 \mathrm{E}+01\end{array}$ & $\begin{array}{l}3.12 E+04 \\
2.92 E-01 \\
2.75 E+02 \\
5.11 E+04 \\
2.82 E-01 \\
6.55 E+00 \\
9.49 E+02 \\
1.89 E+02 \\
1.74 E-03 \\
2.28 E+00 \\
8.20 E-03 \\
3.90 E+05 \\
1.72 E+03\end{array}$ \\
\hline Total & $9.08 \mathrm{E}+04$ & $7.62 \mathrm{E}+03$ & $7.61 \mathrm{E}-01$ & $0^{a}$ & $0^{\infty}$ & $7.63 E+03$ & $3.65 \mathrm{E}+05$ \\
\hline Percent & 92.255 & 7.744 & 0.001 & 0.000 & 0.000 & \multicolumn{2}{|c|}{$\begin{array}{l}\text { Distribution between concrete } \\
\text { and shield }\end{array}$} \\
\hline Percent & & 99.990 & 0.010 & 0.000 & 0.000 & \multicolumn{2}{|c|}{ Distribution in shield layers } \\
\hline
\end{tabular}

${ }^{\circ} 0=$ less than $1 E-9$.

\subsubsection{Estimates of the Concentrations of Activation Products in the Concentric Shield}

Based on the estimated number of curies reported in Sect. 7.1.4.2, the dimensions reported in Table 6, and the configuration as shown in Fig. 4, the estimated concentrations were calculated. Tables 9 and 10 show these results. 


\begin{tabular}{|c|c|c|c|c|c|}
\hline Isotope & Concrete & $\begin{array}{c}\text { Inner } \\
\text { limestone } 1\end{array}$ & Compacted clay & $\begin{array}{c}\text { Outer } \\
\text { limestone } 2\end{array}$ & Soil zone \\
\hline${ }^{3} \mathrm{H}$ & $1.39 \mathrm{E}+01$ & $6.85 E-01$ & $3.94 \mathrm{E}-03$ & $2.33 \mathrm{E}-06$ & 0 \\
\hline${ }^{10} \mathrm{Be}$ & $4.35 \mathrm{E}-06$ & $6.47 \mathrm{E}-06$ & 0 & $3.06 E-13$ & 0 \\
\hline${ }^{14} \mathrm{C}$ & $7.82 \mathrm{E}-02$ & $6.05 \mathrm{E}+03$ & $1.24 \mathrm{E}-05$ & $4.59 \mathrm{E}-07$ & 0 \\
\hline${ }^{22} \mathrm{Na}$ & $1.61 E+01$ & $1.12 \mathrm{E}+00$ & $9.87 \mathrm{E}-03$ & $1.46 \mathrm{E}-07$ & 0 \\
\hline${ }^{26} \mathrm{Al}$ & $2.59 \mathrm{E}-03$ & $5.23 E-06$ & $9.11 \mathrm{E}-07$ & $0.00 \mathrm{E}+00$ & 0 \\
\hline${ }^{36} \mathrm{Cl}$ & 7.04E-04 & $1.45 \mathrm{E}-04$ & $3.58 \mathrm{E}-10$ & $0.00 \mathrm{E}+00$ & 0 \\
\hline${ }^{39} \mathrm{Ar}$ & $2.51 \mathrm{E}-01$ & $2.10 \mathrm{E}-02$ & $2.60 \mathrm{E}-06$ & $3.17 \mathrm{E}-08$ & 0 \\
\hline${ }^{42} \mathrm{Ar}$ & $1.09 \mathrm{E}-02$ & $4.18 \mathrm{E}-03$ & 0 & $0.00 \mathrm{E}+00$ & 0 \\
\hline${ }^{40} \mathrm{~K}$ & $2.66 \mathrm{E}-07$ & $3.85 \mathrm{E}-08$ & $2.99 \mathrm{E}-11$ & $3.62 \mathrm{E}-13$ & 0 \\
\hline${ }^{41} \mathrm{Ca}$ & $3.68 \mathrm{E}-04$ & $5.04 \mathrm{E}-05$ & $2.46 \mathrm{E}-09$ & $4.59 \mathrm{E}-10$ & 0 \\
\hline${ }^{53} \mathrm{Mn}$ & $1.28 \mathrm{E}-05$ & $1.81 \mathrm{E}-07$ & $4.71 \mathrm{E}-11$ & $0^{\alpha}$ & 0 \\
\hline${ }^{54} \mathrm{Mn}$ & $6.71 E+02$ & $7.32 \mathrm{E}+00$ & $1.20 \mathrm{E}+00$ & $0^{a}$ & 0 \\
\hline${ }^{55} \mathrm{Fe}$ & $3.54 \mathrm{E}+00$ & $3.80 \mathrm{E}-02$ & $8.85 \mathrm{E}-05$ & $2.43 \mathrm{E}-08$ & 0 \\
\hline Total & $7.05 \mathrm{E}+02$ & $9.19 E+00$ & $1.21 \mathrm{E}+00$ & $2.99 E-06$ & \\
\hline
\end{tabular}

\begin{tabular}{|c|c|c|c|c|c|}
\hline \multicolumn{6}{|c|}{$\begin{array}{l}\text { Table 10. Conservative estimates of the concentrations (in microcuries per cubic centimeter) } \\
\text { of long-lived nuclides for case } 2 \text { formed after } 30 \text { years of Linac operation } \\
\text { in the last } 20 \mathrm{~m} \text { of the highest beam energy with } 1 \mathrm{MW} \text { of protons at } 1 \mathrm{GeV}\end{array}$} \\
\hline Isotope & Concrete & $\begin{array}{c}\text { Inner } \\
\text { limestone } 1\end{array}$ & Compacted clay & $\begin{array}{c}\text { Outer } \\
\text { limestone } 2\end{array}$ & Soil zone \\
\hline $\begin{array}{l}{ }^{3} \mathrm{H} \\
{ }^{10} \mathrm{Be} \\
{ }^{14} \mathrm{C} \\
{ }^{22} \mathrm{Na} \\
{ }^{26} \mathrm{Al} \\
{ }^{36} \mathrm{Cl} \\
{ }^{39} \mathrm{Ar} \\
{ }^{42} \mathrm{Ar} \\
{ }^{40} \mathrm{~K} \\
{ }^{41} \mathrm{Ca} \\
{ }^{53} \mathrm{Mn} \\
{ }^{54} \mathrm{Mn} \\
{ }^{35} \mathrm{Fe}\end{array}$ & $\begin{array}{l}1.34 \mathrm{E}+01 \\
3.10 \mathrm{E}-06 \\
7.65 \mathrm{E}-02 \\
1.72 \mathrm{E}+01 \\
2.66 \mathrm{E}-03 \\
6.75 \mathrm{E}-04 \\
2.61 \mathrm{E}-01 \\
5.00 \mathrm{E}-06 \\
2.62 \mathrm{E}-07 \\
3.47 \mathrm{E}-04 \\
1.24 \mathrm{E}-05 \\
5.91 \mathrm{E}+02 \\
3.06 \mathrm{E}+00\end{array}$ & $\begin{array}{l}4.41 \mathrm{E}-01 \\
4.25 \mathrm{E}-06 \\
3.68 \mathrm{E}-03 \\
6.57 \mathrm{E}-01 \\
3.11 \mathrm{E}-06 \\
8.07 \mathrm{E}-05 \\
1.31 \mathrm{E}-02 \\
2.95 \mathrm{E}-03 \\
3.28 \mathrm{E}-08 \\
4.57 \mathrm{E}-05 \\
1.13 \mathrm{E}-07 \\
3.61 \mathrm{E}+00 \\
2.29 \mathrm{E}-02\end{array}$ & $\begin{array}{c}2.87 \mathrm{E}-05 \\
0 \\
1.36 \mathrm{E}-08 \\
1.07 \mathrm{E}-06 \\
5.81 \mathrm{E}-08 \\
1.55 \mathrm{E}-11 \\
1.28 \mathrm{E}-07 \\
0 \\
1.54 \mathrm{E}-13 \\
1.13 \mathrm{E}-10 \\
1.30 \mathrm{E}-12 \\
4.16 \mathrm{E}-04 \\
2.64 \mathrm{E}-06\end{array}$ & $\begin{array}{l}0 \\
0 \\
0 \\
0 \\
0 \\
0 \\
0 \\
0 \\
0 \\
0 \\
0 \\
0 \\
0\end{array}$ & $\begin{array}{l}0 \\
0 \\
0 \\
0 \\
0 \\
0 \\
0 \\
0 \\
0 \\
0 \\
0 \\
0 \\
0\end{array}$ \\
\hline Total & $6.25 \mathrm{E}+02$ & 4.57E+00 & 4.47E-04 & & \\
\hline
\end{tabular}

\subsubsection{Retention of Activation Products in the Inner Limestone}

Carbonate minerals, such as limestone, are important sinks for trace elements and control their availability and mobility in natural systems. ${ }^{12}$ When the cationic radii of trace elements are $1 \mathrm{~nm}$ or less, these elements fit into the crystal latices of carbonate minerals and are sequestered in the insoluble matrix of the mineral. The absorption and retention of trace elements by 
carbonate minerals have been documented, and the controlling solid-state diffusion mechanism has been established. ${ }^{13}$ Solid-state diffusion coefficients in carbonate minerals at ambient temperature have been measured ${ }^{14}$ to be near $8 \times 10^{-20} \mathrm{~cm}^{2} / \mathrm{s}$.

Using this diffusion coefficient, the releases from coarse limestone were calculated for 3- and 6-in. riprap for 10,000 years. Table 11 summarizes these results.

\begin{tabular}{|c|c|c|}
\hline \multicolumn{2}{|c|}{$\begin{array}{c}\text { Table 11. Diffusion-controlled fractional release } \\
\text { from 3- and 6-in. riprap limestone } \\
\text { with a } \boldsymbol{D}_{e} \text { of } 8 \times \mathbf{1 0}^{-20} \mathbf{c m}^{2} / \mathbf{s}\end{array}$} \\
\hline Years & 3 in. & 6 in. \\
\hline 50 & $9.98 \mathrm{E}-06$ & $4.99 \mathrm{E}-06$ \\
500 & $3.16 \mathrm{E}-05$ & $1.58 \mathrm{E}-05$ \\
800 & $3.99 \mathrm{E}-05$ & $2.00 \mathrm{E}-05$ \\
1,000 & $4.46 \mathrm{E}-05$ & $2.23 \mathrm{E}-05$ \\
1,500 & $5.47 \mathrm{E}-05$ & $2.73 \mathrm{E}-05$ \\
1,800 & $5.99 \mathrm{E}-05$ & $3.00 \mathrm{E}-05$ \\
2,000 & $6.31 \mathrm{E}-05$ & $3.16 \mathrm{E}-05$ \\
3,000 & $7.73 \mathrm{E}-05$ & $3.87 \mathrm{E}-05$ \\
5,000 & $9.98 \mathrm{E}-05$ & $4.99 \mathrm{E}-05$ \\
8,000 & $1.26 \mathrm{E}-04$ & $6.31 \mathrm{E}-05$ \\
9,000 & $1.34 \mathrm{E}-04$ & $6.70 \mathrm{E}-05$ \\
10,000 & $1.41 \mathrm{E}-04$ & $7.06 \mathrm{E}-05$ \\
\hline
\end{tabular}

Over 2000 to 5000 years, the diffusion-controlled releases of activation products would range between fractions of $3 \times 10^{-5}$ and $1 \times 10^{-4}$ of the initial quantity sequestered within the carbonate mineral phases. These very low releases would prevent groundwater concentrations from reaching any of the limits listed in Table 5.

Figure 5 shows a plot of these release-fraction data. This graph illustrates the rates of diffusion, the slope of the lines, and the decrease over time. This decrease reflects the growing depletion layers near the surface of the minerals and the associated slowing of the release rates.

While diffusion slows with time, the radioactive decay of the activation products remains constant. When one combines diffusion and radioactive decay, it is apparent that the chemical release rates are much lower than the decay rates. If the integrity of the limestone is maintained, the result is that the activation products decay before they can diffuse to the surface of the limestone. 


\section{Diffusion Controlled Release from 3 in. and 6 in. Riprap Limestone for $D e=8 \times 10^{-20} \mathrm{~cm}^{2} / \mathrm{s}$}

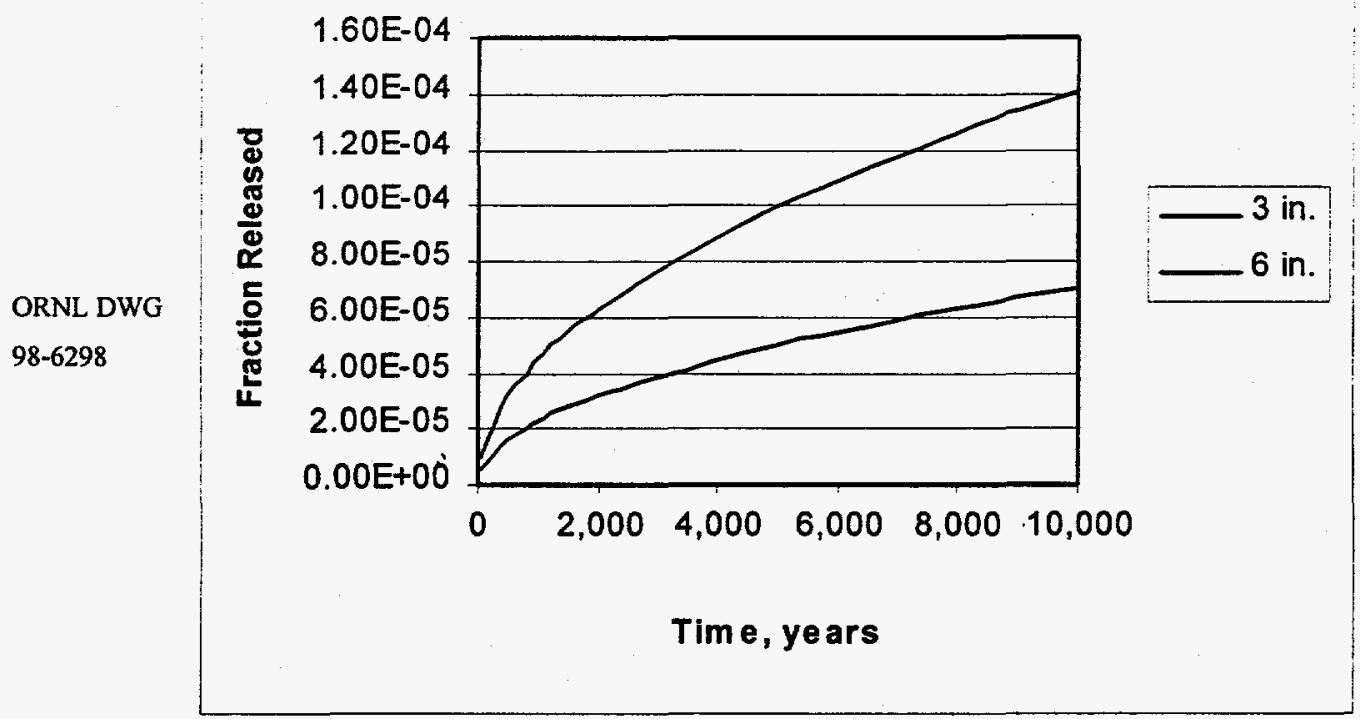

Fig. 5. Diffusion rates slow and the slopes of the plots decrease and flatten out with time.

Figure 6 illustrates the combined effects of diffusion and decay for ${ }^{14} \mathrm{C}$, which has a half-life of 5730 years. As the decay rates overtake the diffusion rates in 3000 to 5000 years, upper limits to the apparent release fractions are reached at $2.8 \times 10^{-5}$ to $5.5 \times 10^{-5}$.

Consequently, even if the outer two barriers, the compacted clay, and the outer limestone capillary break or are compromised, the inherent safety of the system is maintained by the very slow diffusion-controlled release of activation products from the inner coarse limestone and the decay of these activation products. This multibarrier, concentric-shield concept results in longterm, effective protection of the environment. 


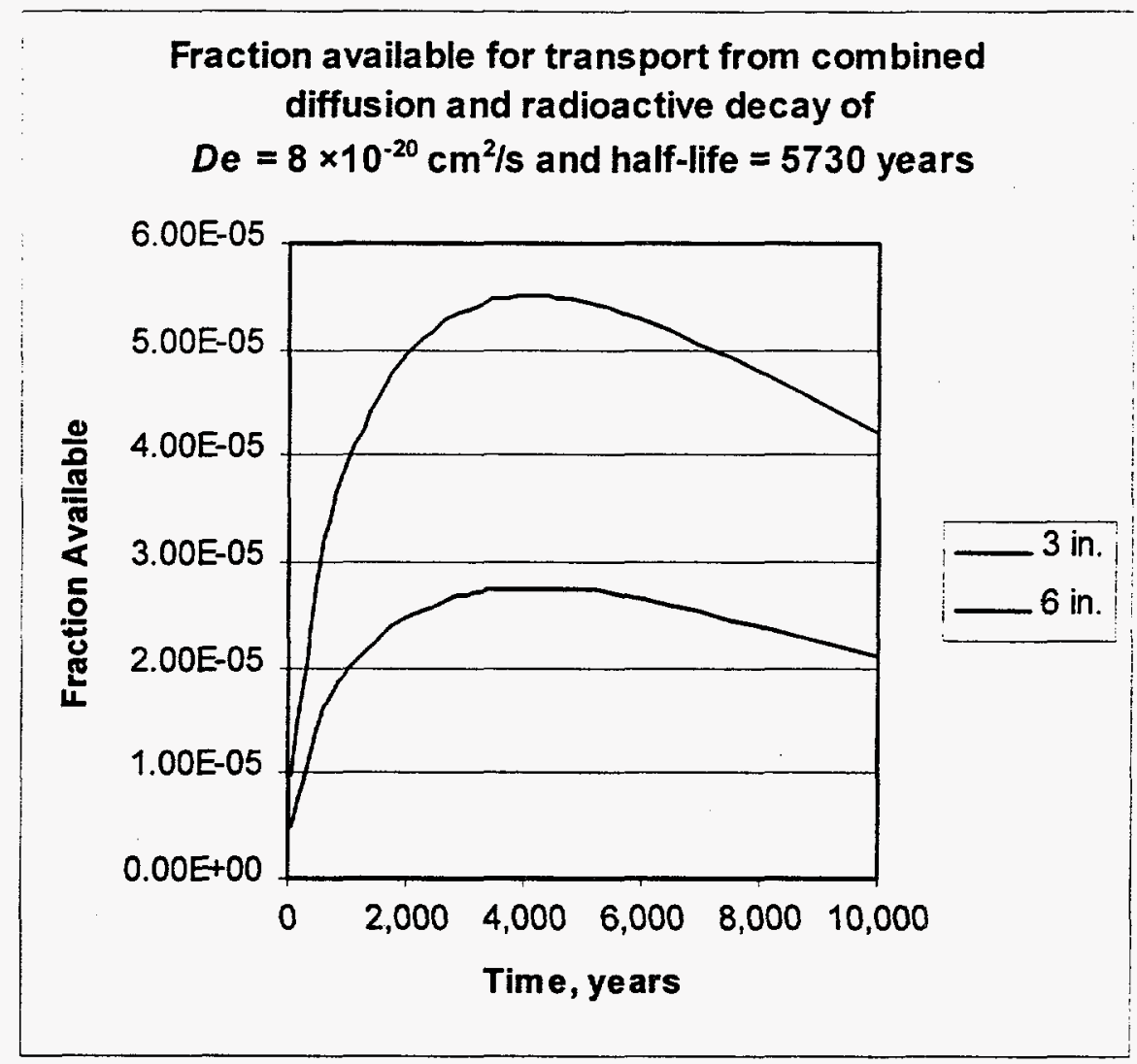

Fig. 6. Combined effects of diffusion and radioactive decay of the activation products from limestone riprap.

\subsubsection{Revised ORR Shield}

Because of the site hydrologic setting of Chestnut Ridge on the ORR, the full implementation of the concentric shielding described in Sect. 7.1.4 is not believed to be required to ensure adequate protection of the local environment. Based on the analyses in this study, an alternative baseline for the design of the proposed ORR SNS facility shielding has been developed that still uses compacted native soils but isolates them from the local hydrology by surrounding the shield berm with a capillary break. Figure 7 shows this concept. 
ORNL OWG 88C-33?

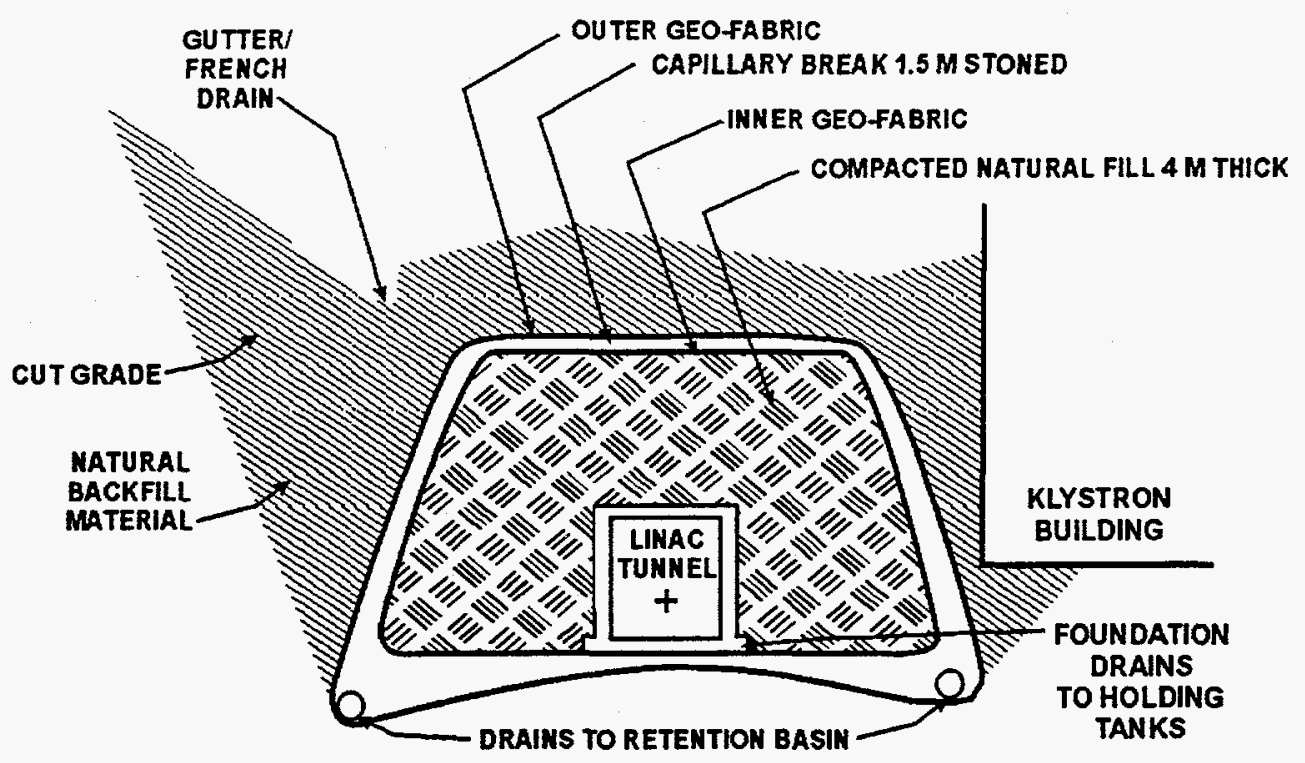

Fig. 7. Linac berm concept.

The capillary break around the entire tunnel shielding system of the SNS. facility tunnels and its foundations consists of three layers. They are $1.5 \mathrm{~m}$ of coarse limestone between two sheets of geofabric, which prevent the infiltration of fine particles from either the surrounding soils or the compacted shield berm. While water vapor can pass through it, the geofabric acts as a fine filter that ensures that the long-term performance of the limestone capillary break is maintained. This encompassing capillary break effectively disconnects the activation products in the compactedsoil shield berm from any potential transport mechanisms into and through the adjacent unsaturated soil of the ORR site vadose zone.

This revised soil-berm concept also incorporates strategically placed drains in the bottom of the capillary break in order to collect and monitor unexpected water under upset conditions to the runoff diversion trenches or catastrophic site erosion and infiltration of fines into the capillary break. If episodic flooding of the capillary break occurs, these drains ensure that the transient water drains away from the inner soil berm before significant leaching can occur. In such a scenario, the water will be sent to a collection basin for monitoring and treatment as required. 
This design, as well as all of the others, uses a thick, reinforced, load-bearing pad to support the SNS tunnel structures and their beam apparatuses. The extra thickness of this concrete pad greatly reduces the formation of activation products in the coarse limestone and native soil below it. For conservatism in the previous activation and transport analyses in Sects. 4, 5, and 6, the concrete pad's thickness was assumed to be the same as the concrete tunnels' thinnest dimension.

\section{REFERENCES}

1. National Spallation Neutron Source Conceptual Design Report, Vols. 1 and 2, NSNS/CDR-1/V1\&2, Lockheed Martin Energy Research Corp., Oak Ridge National Laboratory, Oak Ridge, TN, May 1997.

2. Radiological Safety Aspects of the Operation of Proton Accelerators, STI/DOC/10/283, Technical Report Series No. 283, International Atomic Energy Agency, Vienna, 1988.

3. J. S. Bull et al., "Groundwater Activation at the Superconducting Super Collider: A New Design Model," Health Physics, 73(5), 800-807, November 1997.

4. S. I. Baker, J. S. Bull, and D. L. Goss, "Leaching of Accelerator-Produced Radionuclides," Health Physics, 73(6), 912-919, December 1997.

5. A. Atkins, "The Influence of Waste Form Permeability on the Release of Radionuclides from a Repository," Nuclear Waste Management, 5, 203-214, May 1985.

6. H. W. Godbee et al., "Waste Confinement Systems and Waste-Form Durability," pp. 125-141 in Effective Waste Management: Interfacing Sciences and Engineering with Monitoring and Risk Analysis, ed. R. L. Jolley and R. G. M. Wang, Lewis Publishers, Boca Raton, FL, 1993.

7. J. Dragun, "Overview: How Soil Governs Water Quality," pp. 1-15 in The Soil Chemistry of Hazardous Materials, Hazardous Materials Control Research Institute, Silver Spring, MD, 1988.

8. R. D. Spence et al., "Interpretation of Leaching Data for Cementitious Waste Forms Using Analytical Solutions Based on Mass Transport Theory and Empiricism," pp. 143-161 in Effective Safe Waste Management: Interfacing Sciences and Engineering with Monitoring and Risk Analysis, ed. R. L. Jolley and R. G. Wang, Lewis Publishers, Boca Raton, FL, 1993.

9. L. R. Dole, "Report on Monolith Design and Performance," in Final Report on Remedial Action: Pepper's Steel and Alloys Superfund Site, Medley, Florida, Florida Power and Light Company, Juno Beach, FL, June 1989.

10. C. W. Nestor, Jr., Diffusion from Solid Cylinders, ORNL/SDTM-84, Union Carbide Corp.-Nuclear Division, Oak Ridge National Laboratory, Oak Ridge, TN, January 1980. 
11. Performance Evaluation of the Technical Capabilities of DOE Sites for. Disposal of Mixed Low-Level Waste, p. 19 in Vol. 3: Site Evaluations, DOE/ID-10521/3, Sandia National Laboratories, Albuquerque, NM, March 1996.

12. H. E. Doner and M. Zarvin, "The Role of Carbonates in Trace and Minor Element Chemistry," Advances in GeoEcology, 30, 407-422, 1997.

13 S. L. Stipp et al., " $\mathrm{Cd}^{2+}$ Uptake by Calcite, Solid-State Diffusion, and the Formation of Solid-Solutions: Interface Processes Observed with Near-Surface Sensitive Techniques (XPS, LEED, and AES)," Geochimica et Cosmochimica Acta, 56, 1941-1954, 1992.

14. N. Lahav and G. H. Bolt, "Self-Diffusion of ${ }^{45} \mathrm{Ca}$ into Certain Carbonates," Soil Science, 9(5), 293-299, May 1964. 

Appendix

SAMPLE CALCULATIONS 


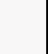

. 
55Fe Released from Berm

ORNL DWG 98-6306

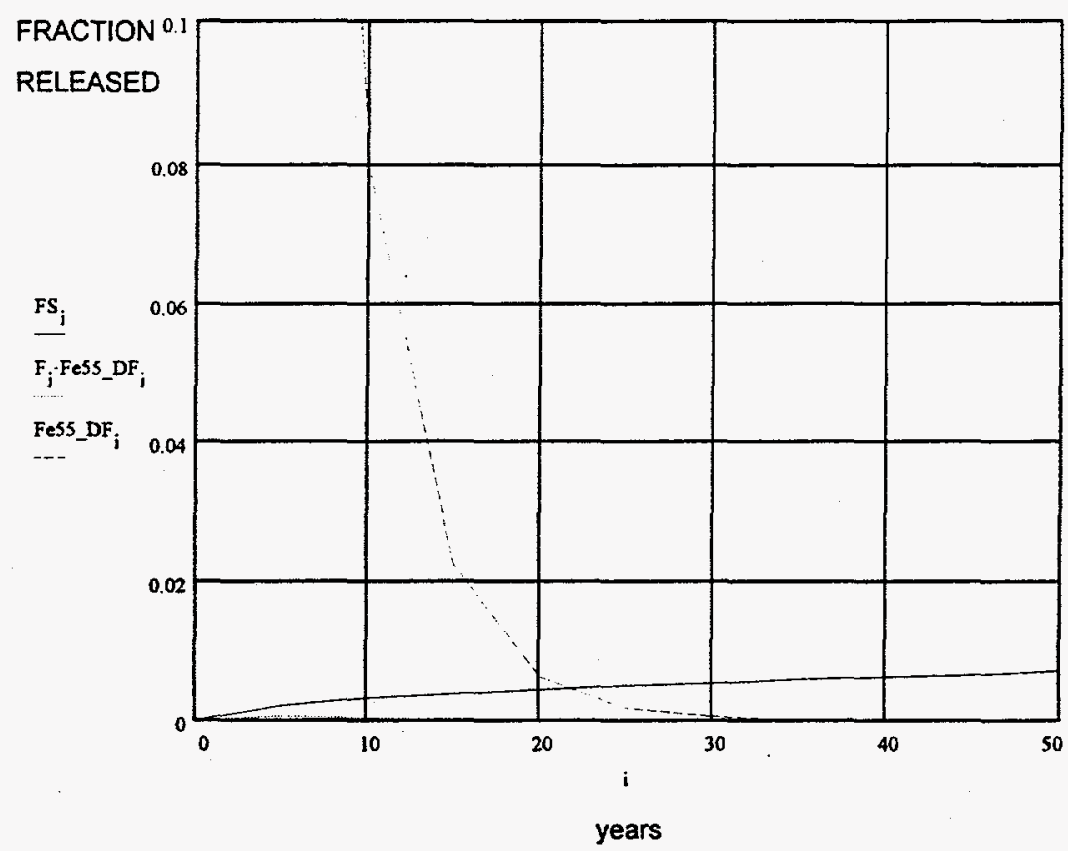

Fe5s_auries $=2.202 \cdot 10^{4} \cdot \mathrm{Ci}$

Recharge_volume

$=1.595 \cdot 10^{4} \cdot \mathrm{m}^{3} \cdot \mathrm{y}^{-1}$

Pore_Fess $i:=\frac{\text { Fes5 } i}{\text { Flow } i}$

Table of Results:

i

\begin{tabular}{|l|}
\hline$y$ \\
\hline 5 \\
\hline $1 \cdot 10$ \\
\hline $1.5 \cdot 10$ \\
\hline $2 \cdot 10$ \\
\hline $2.5 \cdot 10$ \\
\hline $3 \cdot 10$ \\
\hline $3.5 \cdot 10$ \\
\hline $4 \cdot 10$ \\
\hline $4.5 \cdot 10$ \\
\hline $5 \cdot 10$ \\
\hline $5.5 \cdot 10$ \\
\hline $6 \cdot 10$ \\
\hline $6.5 \cdot 10$ \\
\hline $7 \cdot 10$ \\
\hline $7.5 \cdot 10$ \\
\hline $8 \cdot 10$ \\
\hline $8.5 \cdot 10$ \\
\hline $9 \cdot 10$ \\
\hline $9.5 \cdot 10$ \\
\hline $1 \cdot 10^{2}$ \\
\hline
\end{tabular}

$1 \cdot 10^{2}$
FS

\begin{tabular}{|c|}
\hline 0 \\
\hline $2.231 \cdot 10^{-3}$ \\
\hline $3.155 \cdot 10^{-3}$
\end{tabular}

$3.155 \cdot 10^{-3}$

$3.864 \cdot 10^{-3}$

$4.462 \cdot 10^{-3}$

$4.988 \cdot 10^{-3}$

$5.464 \cdot 10^{-3}$

$5.902 \cdot 10^{-3}$

$6.31 \cdot 10^{-3}$

$6.692 \cdot 10^{-3}$

$7.054 \cdot 10^{-3}$

$7.399 \cdot 10^{-3}$

$7.728 \cdot 10^{-3}$

$8.043 \cdot 10^{-3}$

$8.347 \cdot 10^{-3}$

$8.64 \cdot 10^{-3}$

$8.923^{3} \cdot 10^{-3}$

$9.198 \cdot 10^{-3}$

$9.464 \cdot 10^{-3}$

$9.724 \cdot 10^{-3}$

$9.976 \cdot 10^{-3}$

\begin{tabular}{|c|c|}
\hline 5. $\cdot \mathrm{Ci}^{-1}$ & low \\
\hline 0 & $0 . \mathrm{m}^{3}$ \\
\hline 13.802 & $9.463 \cdot 10^{4} \cdot \mathrm{m}^{3}$ \\
\hline 5.484 & $1.893 \cdot 10^{3} \cdot \mathrm{m}^{3}$ \\
\hline \begin{tabular}{|l|}
1.887 \\
\end{tabular} & 0 \\
\hline 0.612 & $2.839 \cdot 10^{\circ} \cdot \mathrm{m}^{3}$ \\
\hline 0.192 & $3.785 \cdot 10^{5} \cdot \mathrm{m}^{3}$ \\
\hline 0.059 & $4.732 \cdot 10^{5} \cdot \mathrm{m}^{3}$ \\
\hline 0.018 & $5,678 \cdot 10^{5} \cdot \mathrm{m}^{3}$ \\
\hline 0.005 & $6624 \cdot 10^{5} \cdot \mathrm{m}^{3}$ \\
\hline 0.002 & \\
\hline $4.763 \cdot 10^{-4}$ & $7.57 \cdot 10^{5} \cdot \mathrm{m}^{3}$ \\
\hline $1.404 \cdot 10^{-4}$ & $8.517 \cdot 10^{5} \cdot \mathrm{m}^{3}$ \\
\hline $4.119 \cdot 10^{-5}$ & $9.463 \cdot 10^{5} \cdot \mathrm{m}^{3}$ \\
\hline $1.205 \cdot 10^{-5}$ & $1.041 \cdot 10^{6} \cdot \mathrm{m}^{3}$ \\
\hline $3.512 \cdot 10^{-6}$ & $1.136 \cdot 10^{6} \cdot \mathrm{m}^{3}$ \\
\hline $1.022 \cdot 10^{-6}$ & $1.23 \cdot 10^{6} \cdot \mathrm{m}^{3}$ \\
\hline $2.964 \cdot 10^{-7}$ & $1.325 \cdot 10^{6} \cdot \mathrm{m}^{3}$ \\
\hline $8.585 \cdot 10^{-8}$ & $1.419 \cdot 10^{6} \cdot \mathrm{m}^{3}$ \\
\hline $2.482 \cdot 10^{-8}$ & $1.514 \cdot 10^{6} \cdot \mathrm{m}^{3}$ \\
\hline $7.165 \cdot 10^{-9}$ & $1.609 \cdot 10^{6} \cdot \mathrm{m}^{3}$ \\
\hline $2.066 \cdot 10^{-9}$ & $1.703 \cdot 10^{6} \cdot \mathrm{m}^{3}$ \\
\hline & $1.798 \cdot 10^{6} \cdot \mathrm{m}^{3}$ \\
\hline & $1.893 \cdot 10^{6} \cdot \mathrm{m}^{3}$ \\
\hline
\end{tabular}

(Pore_Fess $\left.\frac{c c}{\text { microCi }}\right)_{i}$

0

$1.458 \cdot 10^{-4}$

$\frac{2.898 \cdot 10^{-5}}{6.648 \cdot 10^{-6}}$

$1.618 \cdot 10^{-6}$

$4.065 \cdot 10^{-7}$

$1.043 \cdot 10^{-7}$

$2.712 \cdot 10^{-8}$

$7.128 \cdot 10^{-9}$

$1.888 \cdot 10^{-9}$

$5.033 \cdot 10^{-10}$

$1.348 \cdot 10^{-10}$

$3.627 \cdot 10^{-11}$

$9.792 \cdot 10^{-12}$

$2.651 \cdot 10^{-12}$

$7.197 \cdot 10^{-13}$

$1.958 \cdot 10^{-13}$

$5.337 \cdot 10^{-14}$

$1.457 \cdot 10^{-14}$

$3.985 \cdot 10^{-15}$

$1.091 \cdot 10^{-15}$ 
14C Released from Berm

ORNL DWG 98-6307

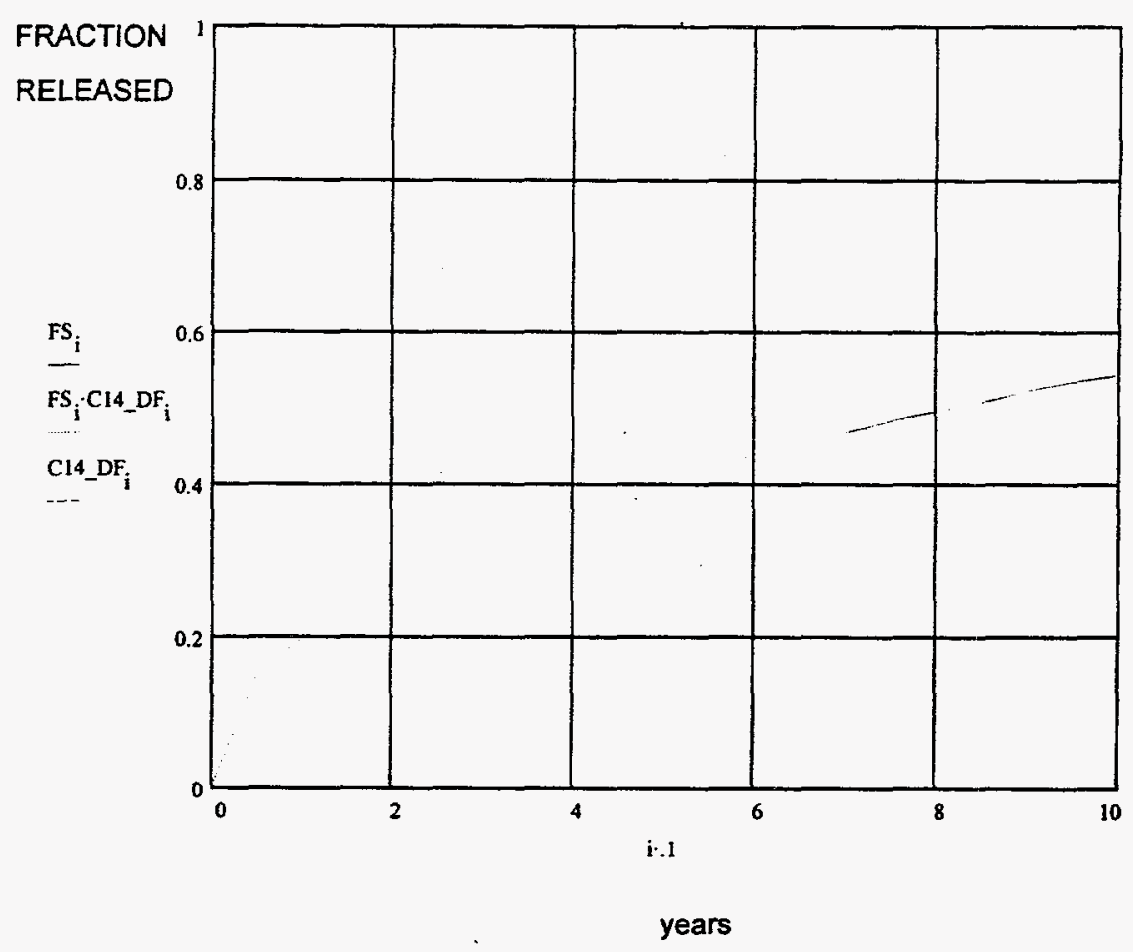

C14_curies $=154.6^{\circ} \mathrm{Ci}$

Recharge_volume $=1.595 \cdot 10^{4} \cdot \mathrm{m}^{3} \cdot \mathrm{y}^{-1}$

Pore_C14 $i=\frac{\text { Cl4 }_{i}}{\text { Flow }_{i}}$

Table of Results:

$\underline{t_{i}}$

\begin{tabular}{|l|}
\hline 5 \\
\hline $5 \cdot 10^{-1}$ \\
\hline 1 \\
\hline 1.5 \\
\hline 2 \\
\hline 2.5 \\
\hline 3 \\
\hline 3.5 \\
\hline 4 \\
\hline 4.5 \\
\hline 5 \\
\hline 5.5 \\
\hline 6 \\
\hline 6.5 \\
\hline 7 \\
\hline 7.5 \\
\hline 8 \\
\hline 8.5 \\
\hline 9 \\
\hline 9.5 \\
\hline 1.10 \\
\hline
\end{tabular}

$\boldsymbol{F}_{\mathbf{i}}$

$\frac{0}{1.512 \cdot 10^{-1}}$

$2.139 \cdot 10^{-1}$

$2.619 \cdot 10^{-1}$

$3.025 \cdot 10^{-1}$

$3.382 \cdot 10^{-1}$

$3.705 \cdot 10^{-1}$

$4.001 \cdot 10^{-1}$

$4.278 \cdot 10^{-1}$

$4.537 \cdot 10^{-1}$

$4.783 \cdot 10^{-1}$

$5.016 \cdot 10^{-1}$

$5.239 \cdot 10^{-1}$

$5.453 \cdot 10^{-1}$

$5.659 \cdot 10^{-1}$

$5.857 \cdot 10^{-1}$

$6.049 \cdot 10^{-1}$

$6.236 \cdot 10^{-1}$

$6.436 \cdot 10^{-1}$

$6.592 \cdot 10^{-1}$

$6.764 \cdot 10^{-1}$
FS

$\frac{0}{1512 \cdot 10^{-1}}$

$1.952 \cdot 10^{-1}$

$2.34 \cdot 10^{-1}$

$2.668 \cdot 10^{-1}$

$2.954 \cdot 10^{-1}$

$3.208 \cdot 10^{-1}$

$3.44 \cdot 10^{-1}$

$3.652 \cdot 10^{-1}$

$3.848 \cdot 10^{-1}$

$4.032 \cdot 10^{-1}$

$4.205 \cdot 10^{-1}$

$4.368 \cdot 10^{-1}$

$4.523 \cdot 10^{-1}$

$4.67 \cdot 10^{-1}$

$4.81 \cdot 10^{-1}$

$4.944 \cdot 10^{-1}$

$5.073 \cdot 10^{-1}$

$5.197 \cdot 10^{-1}$

$5.316 \cdot 10^{-1}$

$5.43 \cdot 10^{-1}$
$\mathrm{Cl4} \cdot \mathrm{Ci}$
\begin{tabular}{|c|}
\hline 0 \\
\hline 23.38 \\
\hline 30.172 \\
\hline 36.176 \\
\hline 41.239 \\
\hline 45.65 \\
\hline 49.584 \\
\hline 53.152 \\
\hline 56.428 \\
\hline 59.465 \\
\hline 62.301 \\
\hline 64.966 \\
\hline 67.481 \\
\hline 69.866 \\
\hline 72.133 \\
\hline 74.297 \\
\hline 76.366 \\
\hline 78.349 \\
\hline 80.254 \\
\hline 82.086 \\
\hline 83.851 \\
\hline
\end{tabular}

\begin{tabular}{l} 
Flow $0 . \mathrm{m}^{3}$ \\
\hline $9.463 \cdot 10^{3} \cdot \mathrm{m}^{3}$ \\
\hline $1.893 \cdot 10^{4} \cdot \mathrm{m}^{3}$ \\
\hline $2.839 \cdot 10^{4} \cdot \mathrm{m}^{3}$ \\
\hline $3.785 \cdot 10^{4} \cdot \mathrm{m}^{3}$ \\
\hline $4.732 \cdot 10^{4} \cdot \mathrm{m}^{3}$ \\
\hline $5.678 \cdot 10^{4} \cdot \mathrm{m}^{3}$ \\
\hline $6.624 \cdot 10^{4} \cdot \mathrm{m}^{3}$ \\
\hline $7.57 \cdot 10^{4} \cdot \mathrm{m}^{3}$ \\
\hline $8.517 \cdot 10^{4} \cdot \mathrm{m}^{3}$ \\
\hline $9.463 \cdot 10^{4} \cdot \mathrm{m}^{3}$ \\
\hline $1.041 \cdot 10^{5} \cdot \mathrm{m}^{3}$ \\
\hline $1.136 \cdot 10^{5} \cdot \mathrm{m}^{3}$ \\
\hline $1.23 \cdot 10^{5} \cdot \mathrm{m}^{3}$ \\
\hline $1.325 \cdot 10^{5} \cdot \mathrm{m}^{3}$ \\
\hline $1.419 \cdot 10^{5} \cdot \mathrm{m}^{3}$ \\
\hline $1.514 \cdot 10^{5} \cdot \mathrm{m}^{3}$ \\
\hline $1.609 \cdot 10^{5} \cdot \mathrm{m}^{3}$ \\
\hline $1.703 \cdot 10^{5} \cdot \mathrm{m}^{3}$ \\
\hline $1.798 \cdot 10^{5} \cdot \mathrm{m}^{3}$ \\
\hline $1.893 \cdot 10^{5} \cdot \mathrm{m}^{3}$ \\
\hline
\end{tabular}

$\left(\text { Pore_C14 } \frac{c c}{\text { microCi }}\right)_{i}$

0

0.002

0.002

0.001

0.001

$9.648 \cdot 10^{-4}$

$8.733 \cdot 10^{-4}$

$8.024 \cdot 10^{-4}$

$7.454 \cdot 10^{-4}$

$6.982 \cdot 10^{-4}$

$6.584 \cdot 10^{-4}$

$6.241 \cdot 10^{-4}$

$5.943 \cdot 10^{-4}$

$5.679 \cdot 10^{-4}$

$5.445 \cdot 10^{-4}$

$5.234 \cdot 10^{-4}$

$5.044 \cdot 10^{-4}$

$4.87 \cdot 10^{-4}$

$4.712 \cdot 10^{-4}$

$4.565 \cdot 10^{-4}$

$4.43 \cdot 10^{-4}$ 


\section{INTERNAL DISTRIBUTION}

1. J. R. Alonso

2. B. R. Appleton

3. F. G. Bale

4. J. M. Begovich

5. J. E. Cleaves

6. A. G. Croff

7. J. R. DeVore

8-12. L. R. Dole

13. J. J. Ferrada

14. C. W. Forsberg

15. T. A. Gabriel

16. J. O. Johnson
17. R. L. Johnson

18. J. R. Lawson

19. L. E. McNeese

20. R. C. Peters

21. D. E. Reichle

22. J. P. Schubert

23. M. B. Sears

24. S. N. Storch

25. Central Research Library

26. Document Reference Center

27-28. ORNL Laboratory Records

\section{EXTERNAL DISTRIBUTION}

29 D. J. Bean, Sr., Enterprise Advisory Services, Inc., 663 Emory Valley Road, Oak Ridge, Tennessee 37830-7751

30. D. Combs, Enterprise Advisory Services, Inc., 663 Emory Valley Road, Oak Ridge, Tennessee 37830-7751 